\title{
An unknown hotspot of plant diversity in the heart of the Central Apennine: flora and vegetation outline of Mt. Pozzoni-St. Rufo valley (Cittareale, Rieti)
}

\author{
Edda Lattanzi', Eva Del Vico², Roberto Tranquilli', \\ Emmanuele Farris ${ }^{4}$, Michela Marignani ${ }^{5}$, Leonardo Rosati ${ }^{6}$
}

I Via V. Cerulli 59, 00143 Roma, Italy 2 Dipartimento di Biologia Ambientale, Sapienza Università di Roma, P.le A. Moro 5, 00185 Roma, Italy 3 Via Achille Mauri 11, 00135 Roma, Italy 4 Department of Chemistry and Pharmacy, University of Sassari, Via Piandanna 4, 07100 Sassari, Italy 5 Department of Life and Environmental Sciences - Botany Division, University of Cagliari, Via Sant'Ignazio da Laconi 13, 09123 Cagliari, Italy 6 School of Agriculture, Forestry, Food and Environment, Via dell'Ateneo Lucano 10, University of Basilicata, 85100 Potenza, Italy

Corresponding author: Eva Del Vico (evadelvico@gmail.com)

Academic editor: Manuel Luján | Received 9 January 2021 | Accepted 9 March 2021 | Published 31 May 2021

Citation: Lattanzi E, Del Vico E, Tranquilli R, Farris E, Marignani M, Rosati L (2021) An unknown hotspot of plant diversity in the heart of the Central Apennine: flora and vegetation outline of Mt. Pozzoni-St. Rufo valley (Cittareale, Rieti). PhytoKeys 178: 111-146. https://doi.org/10.3897/phytokeys.178.62947

\begin{abstract}
Surprisingly enough, Italy still has some botanically unexplored areas; among these there are some territories between Lazio, Umbria and Abruzzo not included in any protected area. The study area, ranging for 340 ha, includes the mountainous area of Mt. Pozzoni-Mt. Prato-St. Rufo valley, which forms the upper part of the river Velino basin, located in the territory of the municipality of Cittareale (Rieti, Lazio), at an elevation from 1150 to $1903 \mathrm{~m}$ a.s.l. The substrate is mainly made of marly limestone of the MesoCenozoic Umbria-Marche sedimentary succession. The climate is Temperate and comprises vegetation belts from the montane to sub-alpine. Land cover is dominated by pastures and deciduous forests, with only a few hay meadows. 794 entities have been detected: $16 \%$ are considered rare or very rare for the regional territory with several floristic novelties for the regional flora, $6 \%$ of the total was found to be endemic to Italy and only eight taxa were aliens. Four taxa are new for the regional flora of Lazio: Arum cylindraceum, Alopecurus pratensis subsp. pratensis, Hieracium bupleuroides and Trinia glauca subsp. glauca. Forest vegetation is represented by beech forests, while dry grasslands are the most widespread vegetation type. The greatest phytocoenotic diversity was found within the secondary pastures. Particularly interesting is the plant community with Iris marsica, which suggests that limestone mountain ledges can represent a primary habitat for this endemic species of the Central Apennine. The presence of several habitats listed
\end{abstract}

Copyright Edda Lattanzi et al. This is an open access article distributed under the terms of the Creative Commons Attribution License (CC BY 4.0), which permits unrestricted use, distribution, and reproduction in any medium, provided the original author and source are credited. 
in the EU Habitat Directive indicates how the lack of detailed territorial knowledge can lead to the nondesignation of conservation sites in areas of high naturalistic value. These findings showed that botanical explorations in territories which are still not known could contribute significantly to the identification of areas of high interest in conserving plant diversity.

\section{Keywords}

endemic species, floristic records, Italy, phytosociology, Red lists

\section{Introduction}

The study of Central Apennine attracted the attention of several botanists in the past (e.g. Gravina 1812; Tenore 1830; Paolucci 1891; Crugnola 1900; Grande 1904; Zodda 1931, 1954; Anzalone 1951; Montelucci 1952, 1953) for the presence of the highest peaks of the Italian peninsula and of a rich flora, characterized by the presence of numerous endemics (Conti 2004). The floristic knowledge of this territory has since been progressively increased by numerous contributions (e.g. Conti 1998, 2004; Ballelli 2003; Tondi et al. 2003; Di Pietro et al. 2008; Iocchi et al. 2010; Gubellini et al. 2014; Falcinelli et al. 2016; Conti et al. 2018; Rosati et al. 2020) and some synopses have recently involved the National Parks of the Central Apennine (Conti and Bartolucci 2015, 2016; Conti et al. 2019). On a regional scale, the state of floristic knowledge of this territory has been synthesized in the recent checklist of Italian vascular flora by Conti et al. (2005) and Bartolucci et al. (2018) whilst, for Lazio, a detailed flora was published by Anzalone et al. (2010). Despite this, as already highlighted in previous publications (Scoppola and Blasi 2005; Bartolucci et al. 2012, 2019), floristic exploration of several areas of the Central Apennine cannot be considered exhaustive and homogeneous throughout the territory; consequently, particularly interesting species, of high phytogeographic interest, are still being discovered (e.g. Cancellieri et al. 2017; Filibeck et al. 2020)

As for interior areas of the Central Apennine, the attention of botanists has always been directed towards the main mountain ranges (e.g. Terminillo, Sibillini, Laga), thus large portions of the surrounding territory have been neglected, both by floristic and vegetational studies. This is the case with the area constituting the upland drainage basin of Velino River, located between Lazio, Umbria and Abruzzo administrative regions where only wet meadows were studied (Venanzoni 1992). Some studies on a national scale had already highlighted that this area lacked specific floristic knowledge; in particular the Map of the Important Plant Areas in Italy (Blasi et al. 2009, 2011) indicated how this part of the Central Apennine is surrounded by areas of high interest for plant conservation, suggesting that covering such a gap of knowledge (Hortal et al. 2015) could lead to interesting results for its flora and vegetation.

In this study we present the results of the flora and vegetation surveys conducted by the authors during the period 2008-2010 in the mountainous area of Mt. Pozzoni-Mt. Prato-St. Rufo valley, which represents the upland drainage basin of the Velino River. 


\section{Data and methods}

\section{Study area}

The study area is included within the municipality of Cittareale (province of Rieti), belonging to the Lazio administrative region. It extends for 343 ha, at altitudes ranging between 1150 and $1903 \mathrm{~m}$ a.s.l. (Fig. 1). The study area includes the peak of Mt. Pozzoni $(1903 \mathrm{~m})$, extends to southeast including the mountain ridge of Mt. LaghettoMt. Prato $(1834 \mathrm{~m})$, ending in the south almost in correspondence of the provincial road Cittareale-Norcia. To the west the limit runs along the watershed that delimits the valley of St. Rufo-Pozzoni (Fig. 1).

The substrate is mainly made up of Meso-Cenozoic marly limestone ("Scaglia" formation) belonging to the Umbria-Marche succession; these sedimentary layers are heavily fractured and faulted, due to the proximity of a regional overthrust overlapping the Sibillini unit on the Gran Sasso-Cittareale unit (Calamita et al. 1995). The head of the valley is modeled by an evident glacial cirque, with a threshold placed at an altitude of $1660 \mathrm{~m}$; the valley bottom is largely covered with slope debris, mixed with sediments of fluvio-glacial origin partly terraced and dissected by the upper course of Velino River. Along St. Rufo valley, an important karst cavity, $3 \mathrm{~km}$ long and over $400 \mathrm{~m}$ deep, opens at about $1440 \mathrm{~m}$ set in the marly limestones of Scaglia rossa formation (Gatti and Uffreduzzi 1989); the cavity has returned interesting fossil remains of bats, testifying to a cold period fauna dated to the end of the Pleistocene (Argenti et al. 2008).

Following the bioclimatic classification of Rivas-Martínez et al. (2011), the climate is Temperate oceanic/semi-continental, with the presence of two phytoclimatic belts along the altitudinal gradient, from the lower supratemperate to the lower orotemperate of the cacuminal areas; ombrotypes are comprised between humid and hyperhumid (Pesaresi et al. 2017).

The land cover is dominated by secondary grasslands, deciduous woodlands and small patches of artificial coniferous forest. Meadows and fallows are very limited and arable lands are nowadays completely missing in the study area. In the past they must have been quite common in the lower part of the valley, as evidenced by the presence of several still visible terraced parcels. Forests are used regularly as coppices and summer grazing of cattle and sheep is still widespread in this sector, together with horse grazing, which is conversely continuously present almost all year round.

The study area does not comprise any protected area, even if some Natura 2000 sites, defined according to European Union Habitat Directive (European Union 1992), are present in the neighboring territory of the Umbria region.

\section{Flora and vegetation survey}

The flora of the studied area was investigated in depth by carrying out numerous herborizations and field excursions, both in spring, summer and autumn, during three consecutive years from 2008 to 2010 . Identification of vascular plants was mostly based 

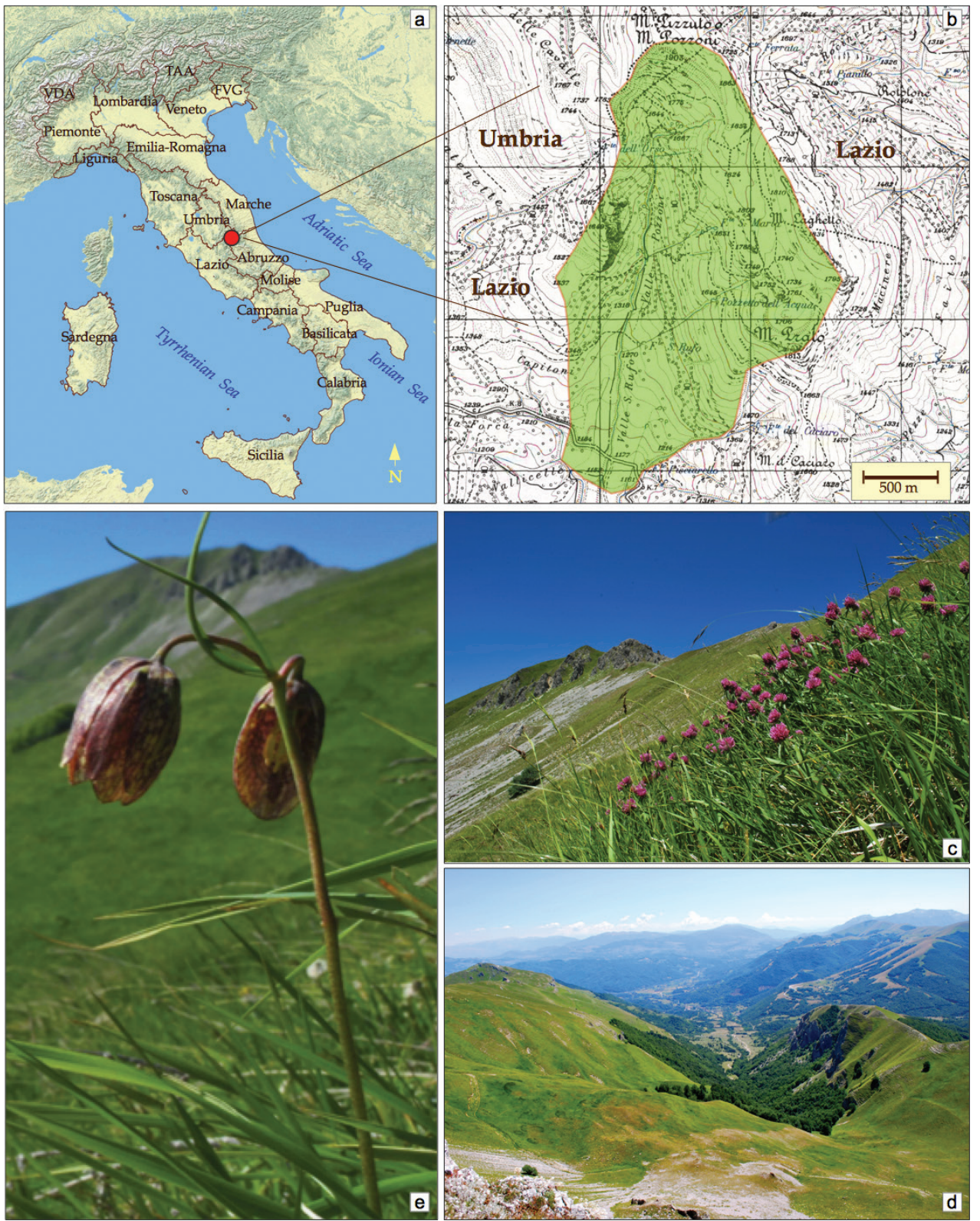

Figure I. Study area location (a) and its landscape (c-e) b the limits of study area drawn on I.G.M.I-1:25,000 topographic map $\mathbf{c}$ high mountain pastures of Mt. Pozzoni dominated by Brachypodium genuense (DC.) Roem. et Schult. with Trifolium alpestre L. e Fritillaria montana Hoppe ex W.D.J.Koch, a rare species considered "Near Threatened" for extinction risk. Photos: R. Tranquilli and E. Del Vico.

on Pignatti (1982) and Flora Europaea (Tutin et al. 1968, 1972, 1976, 1980, 1993). Taxa delimitation was based on Anzalone et al. (2010) and nomenclature accords to Bartolucci et al. (2018), Galasso et al. (2018) and the subsequent updates summarized 
in the "Portal to the Flora of Italy" (http://dryades.units.it/floritaly/). Families of vascular plants correspond to APG IV (2016), whereas life forms and chorotypes were retrieved from Pignatti (1982). Exsiccata are preserved in Herbarium Lucanum (HLUC), Herbarium Del Vico (Roma) and Herbarium Lattanzi (Roma), the latter is now moving to Herbarium Sapienza (RO). In the floristic list we reported the rarity level in the regional flora of Lazio for each taxon according to Anzalone et al. (2010), adopting three levels: rare, medium rare and very rare (coded as R, MR, RR). New taxa for the regional flora were marked with an asterisk. Italian endemics were retrieved from Bartolucci et al. (2018). As for alien taxa, we also reported the status of naturalization in the study area following the same codes used by Galasso et al. (2018). For each taxon the status of threatened species was derived by the published Italian Red lists (Conti et al. 1992, 1997) and updated, when new assessments were available, according to the most recent ones (Rossi et al. 2013; Orsenigo et al. 2020). Vegetation was analyzed using the phytosociological method (Braun-Blanquet 1965) by carrying out 30 surveys of the main vegetation types in the territory located in the field with a GPS unit with \pm $5 \mathrm{~m}$ accuracy. The syntaxonomic nomenclature, at the level of alliance, order and class, follows the 'Prodrome of the Italian Vegetation' (Biondi et al. 2014).

Main vegetation types were identified through multivariate methods, Hierarchical Cluster Analysis and NMDS ordination. For each vegetation type a floristic-ecological description and the syntaxonomic framework were provided.

\section{Results}

Flora

794 taxa of vascular plants were identified, belonging to 331 genera and 69 families (Appendix 1). The families with more than 40 taxa (Fig. 2a) were: Asteraceae (107), Poaceae (71), Fabaceae (67), Caryophyllaceae (46) and Rosaceae (42). The most diverse genera were Trifolium (19), Carex (16), Ranunculus (14), Hieracium (13) and Silene (12) (Fig. 2b). Hemicryptophytes were the dominant life form (52\%), followed by therophytes (21\%) and geophytes (13\%) (Fig. 2c). As for chorology, (Fig. 2d) species with Eurasian-Paleotemperate distribution prevailed (39\%), slightly exceeding the Mediterranean element (29\%). The Mediterranean group was mainly composed of Eurimediterranean (15\%) and Mediterranean-Mountain species (6\%). A significant contingent of Circumboreal species was also present $(6 \%)$ while only a few species displayed eastern chorotypes (e.g. SE-European and Pontic).

Forty-seven $t a x a$, approximately $6 \%$ of the total, were found to be endemic to Italy (Table 1). Only eight taxa were found to be aliens, among these Malus domestica (Suckow) Borkh., Matricaria discoidea DC., Medicago sativa L. and Veronica persica Poir. can be considered naturalized, whereas Abies alba Mill., Abies cephalonica Loudon, Picea abies (L.) H. Karst. and Pinus nigra J.F. Arnold subsp. nigra have been observed only as planted in reforested areas. 


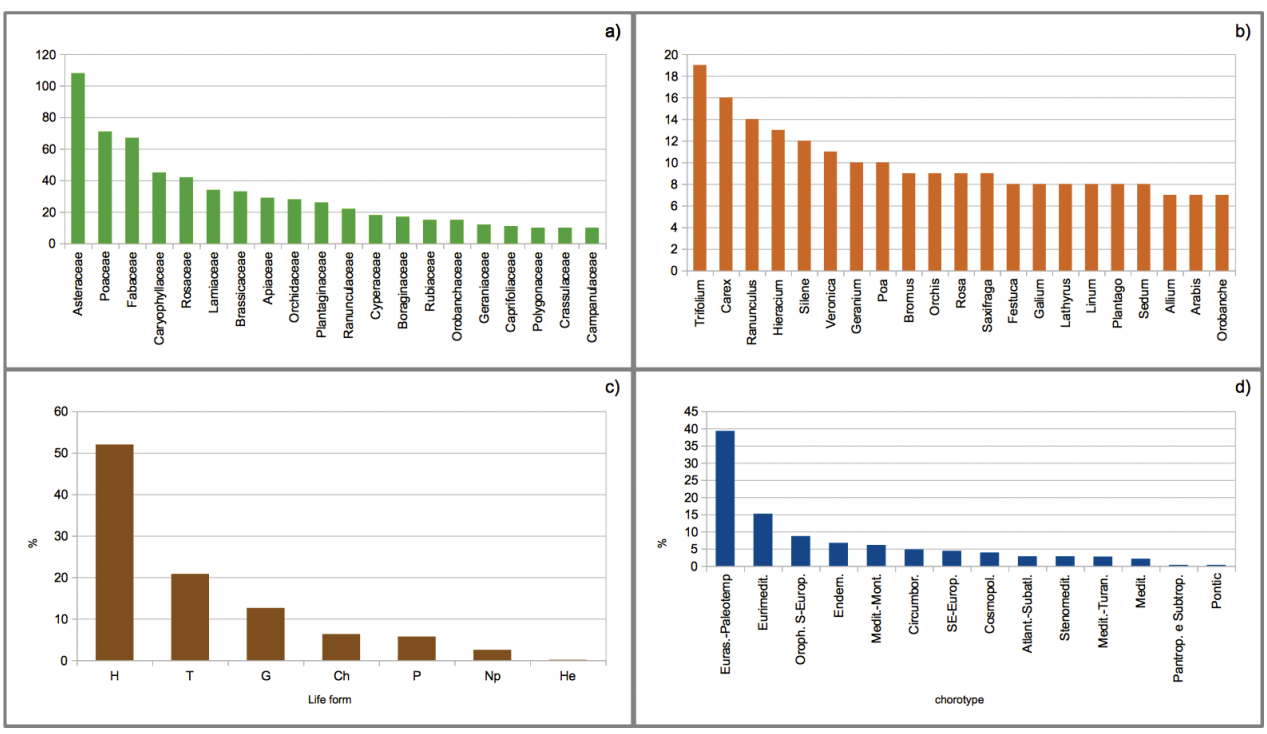

Figure 2. a number of taxa per family; only the families with more than 10 taxa are shown $\mathbf{b}$ number of taxa per genus; genera containing more than 7 taxa are shown $\mathbf{c}$ life form percentages $\mathbf{d}$ chorological spectrum of the detected flora in the study area.

Two taxa, Arum cylindraceum Gasp. and Corydalis densiflora C.Presl subsp. apennina F.Conti, Bartolucci \& Uzunov have been recorded for the first time for Lazio during this research, whereas four taxa whose presence was considered doubtful for Lazio have been confirmed (Alopecurus pratensis L. subsp. pratensis, Hieracium bupleuroides C.C.Gmel., Scandix macrorhyncha C.A.Mey and Trisetaria flavescens (L.) Baumg. subsp. flavescens). These floristic records at regional level have been anticipated by Del Vico et al. (2014). However, probably due to oversight, Alopecurus pratensis subsp. pratensis is still considered to be confirmed for Lazio in the continuously updated database of the Portal to the Flora of Italy (Available at http:/dryades.units.it/floritaly, accessed: 16/11/2020). Additionally, we herein confirm the presence of Trinia glauca (L.) Dumort. subsp. glauca, previously considered recorded erroneously for Lazio (Bartolucci et al. 2018).

Thirty-four taxa (Table 2) are considered very rare at the regional level (2010). Considering all the rare species (R, MR and RR), these taxa represent altogether approximately $20 \%$ of the studied flora.

The following 15 species have been identified as being at risk of extinction in the first published Italian red lists (Conti et al. 1992, 1997): Iris marsica I. Ricci et Colas., Achillea tomentosa L., Carex panicea L., Fritillaria montana Hoppe ex Koch, Gentiana lutea L. subsp. lutea, Gentiana utriculosa L., Klasea nudicaulis (L.) Fourr., Lathyrus nissolia L., Lilium bulbiferum L. subsp. croceum (Chaix) Jan, Narcissus poëticus L., Onobrychis arenaria (Kit.) DC. subsp. arenaria, Ornithogalum comosum L., Scorzonera purpurea L., Trifolium phleoides Willd. and Trisetaria villosa (Bertol.) Banfi et Soldano. 
Table I. List of endemic taxa recorded in the study area.

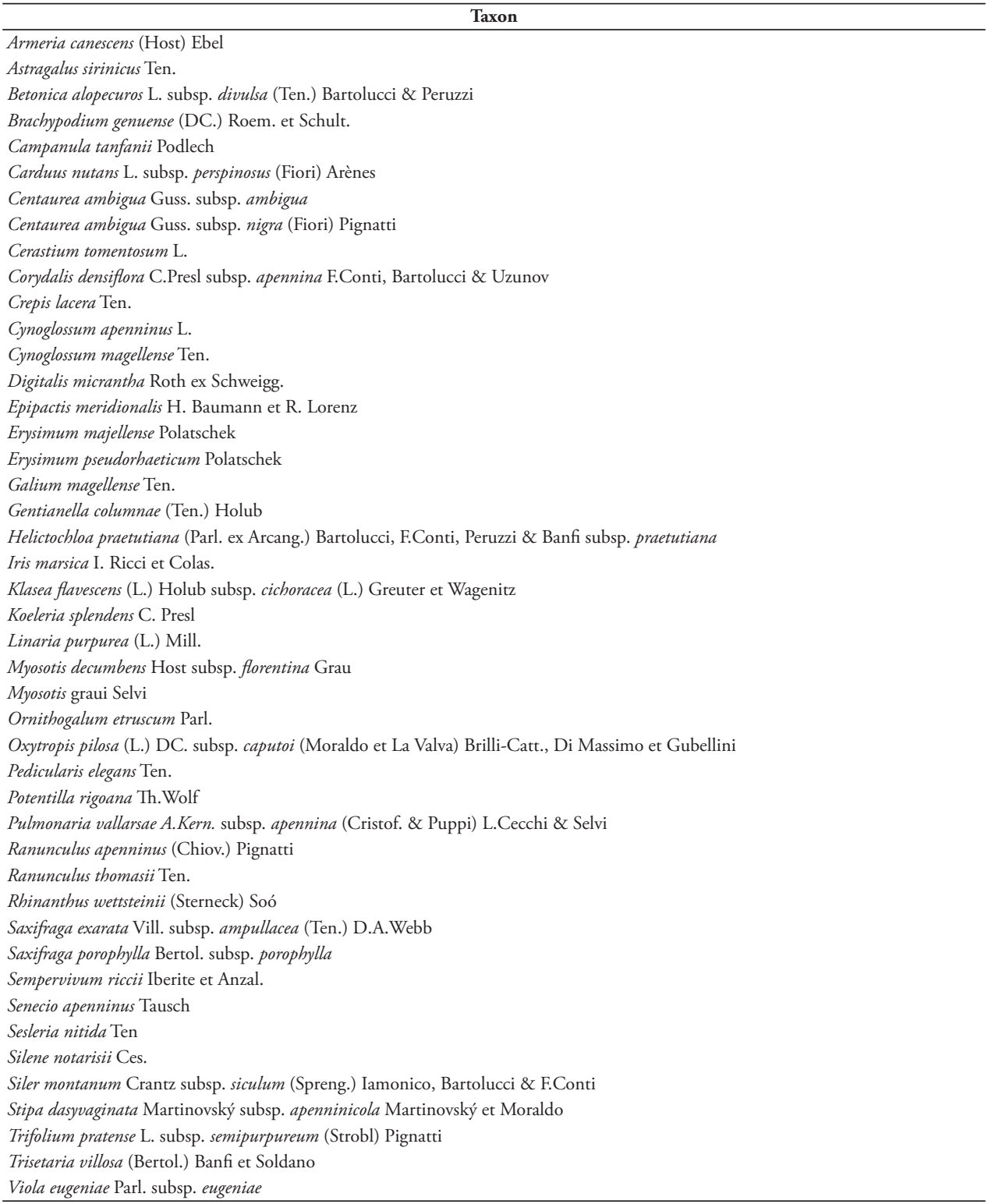

Meanwhile, in the most recent ones (Rossi et al. 2013; Orsenigo et al. 2020), excluding the species classified as "Least Concern", Viola kitaibeliana Schult. was listed as "Endangered", Epipactis meridionalis H. Baumann et R. Lorenz as "Vulnerable" and Fritillaria montana, Gentiana lutea, Iris marsica and Senecio scopolii Hoppe et Hornsch. ex Bluff et Fingerh. as "Near Threatened". 
Table 2. List of taxa found in the study area considered very rare (RR) at regional level including those that are new records for Lazio with respect to Anzalone et al. (2010).

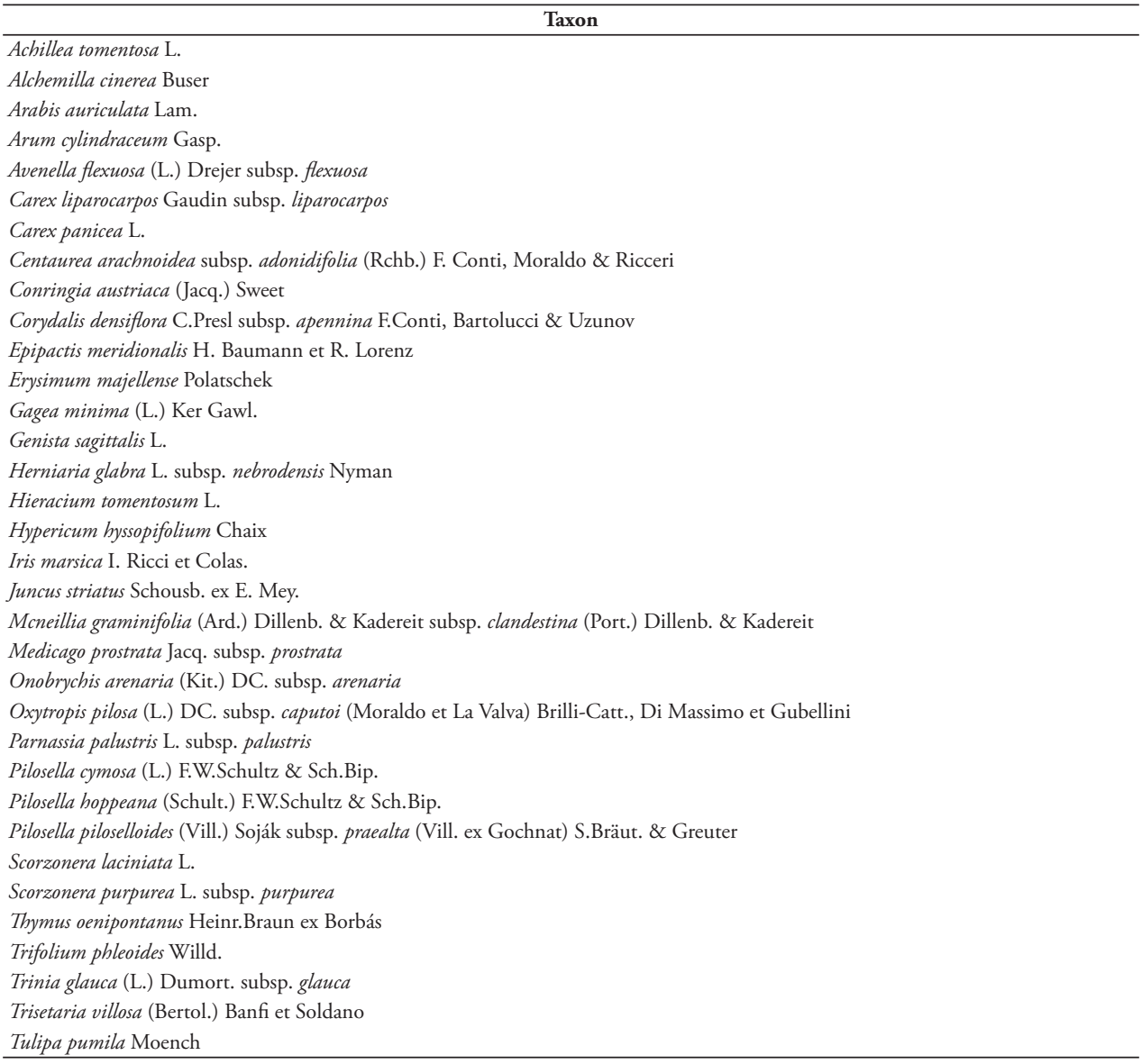

\section{Plant community descriptions}

Hierarchical cluster analysis and NMDS ordination (the latter not shown) enabled the detection of 10 clusters that were clearly interpretable, floristically and ecologically, as shown in Fig. 3. A further inspection of the ordered table led to the identification of 12 plant communities (some of these represented by only one relevè); the greatest phytocoenotic diversity was found within the secondary pastures. The relevès of these communities are presented in Suppl. material 1: Table S1 and described in detail below.

\section{Forests and shrublands}

Forest vegetation in the Mt. Pozzoni valley is represented almost exclusively by beech forests (cluster 1). Quercus cerris woodlands are present only on the edges of the investigated area on southern exposures, but they are widespread at lower altitudes where flyschoid substrates emerge. Small patches of coniferous plantation, planted for reforestation pur- 


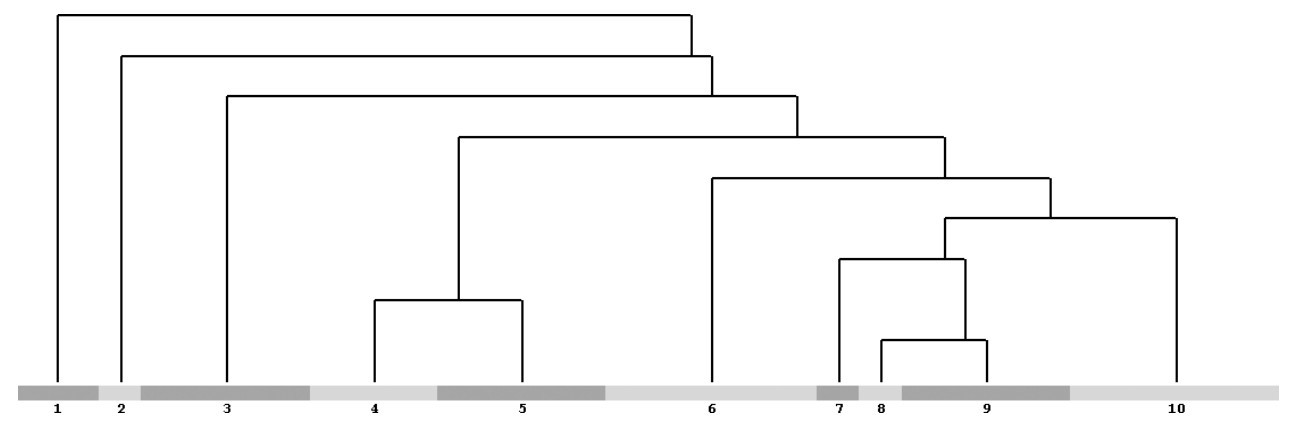

Figure 3. Hierarchical clustering resulting from Modified TWINSPAN analysis. Cluster 1) Fagus sylvatica woodlands; 2) Amelanchier ovalis forest edges; 3) Saxifraga callosa chasmophytic vegetation; 4) Cynosurus cristatus hay meadows; 5) Bromopsis erecta montane grasslands; 6) Iris marsica community; 7) Rumex scutatus screes vegetation; 8) Paronychia kapela rocky outcrops vegetation; 9) upper-montane grasslands, including also the Brachypodium genuense community and the Astragalus sempervirens community; 10) chamaephytes-rich dry grasslands.

poses (e.g. Pinus nigra, Abies spp.) are also present. Fagus sylvatica forests cover approx. 60 ha, forming a more or less continuous belt between 1350 and $1700 \mathrm{~m}$ a.s.l.; they are managed as coppices with stands, meanwhile mixed aged and old-growth formations are absent. Tree layer is always dominated by Fagus sylvatica, frequently accompanied by Acer pseudoplatanus and Acer opalus subsp. obtusatum. In relevè no. 1, surveyed at $1500 \mathrm{~m}$, in the tree layer we also found Tilia plathyphyllos and Prunus avium, while in rel. no. 2, placed at $1360 \mathrm{~m}$, the presence of Quercus cerris and Acer campestre can be noted. In the herb layer, nemoral species commonly found in mesic and beech forests are present, such as Cardamine bulbifera, Pulmonaria vallarsae subsp. apennina, Moehringia trinervia, Rabelera holostea (= Stellaria holostea); from a phytosociological point of view most of these species are typical of Fagetalia sylvaticae order. Related to the altitude, the second relevè in table $S 1$ hosts a larger contingent of species having a relatively thermophilic character, such as Lathyrus venetus, Cyclamen hederifolium, Cephalanthera damasonium, Sesleria autumnalis, Viola odorata, which also characterize the lower altitudinal vegetation belt dominated by oak forests. These relevès can be classified in the alliance Aremonio agrimonioidis-Fagion sylvaticae (Querco roboris-Fagetea sylvaticae, Fagetalia sylvaticae) describing the beech forests of E-Europe, Balkans and extending to Central-Northern Apennine (Biondi et al. 2014). The beech woods at lower altitudes, as evidenced by the relevè no. 2, show a floristic composition referable to Lathyro veneti-Fagetum sylvaticae, a widespread association which frames beech forests of lower supratemperate belt of the Central Apennines mainly on limestones (Blasi et al. 2010). At higher altitudes, generally above $1500 \mathrm{~m}$, it is possible to observe a clear decrease in the number of species of Quecetalia pubescenti-petraeae, indicating a shift towards the association Cardamino kitaibelii-Fagetum sylvaticae Ubaldi ex Ubaldi 1995. The latter represents the potential vegetation of the upper supratemperate belt, which in the St. Rufo valley is almost completely substituted by the secondary grasslands belonging to Festuco-Brometea class.

The edge of the beech forest (cluster 2), in some cases, presents characteristic preforest shrub formations, as evidenced by relevè no. 3, physiognomically dominated by 
Amelanchier ovalis, Atadinus fallax (=Rhamnus alpina subsp. fallax) and Sorbus aria, accompanied by smaller shrubs of Rosa montana, Crataegus laevigata and Cytisophyllum sessilifolium. These formations can be attributed to the association Rhamno alpinaeAmelanchieretum ovalis (Berberidion vulgaris, Prunetalia spinosae, Rhamno-Prunetea), described for Sibillini mountains by Pedrotti (1994) and revised by Cutini et al. (2002), even if the herb layer appeared strongly impoverished.

Along the river incisions, especially in the middle and lower part of the investigated area, there are other shrub and pre-forest formations of difficult syntaxonomic classification at association level, dominated by Corylus avellana and Acer spp., which are not represented in our surveys.

\section{Sparse vegetation of outcrops}

Limestone rocky walls, from $1400 \mathrm{~m}$ up to the highest peak of Mt. Pozzoni, are colonized by a characteristic chasmophytic vegetation dominated by Saxifraga callosa (rel. 4-6) with the presence of Saxifraga paniculata, Campanula tanfanii and Saxifraga exarata subsp. ampullacea (cluster 3). Even if Trisetum villosum was not found within the relevès, this species is present in such habitats of the study area (see floristic list). The overall floristic composition of these coenoses allows us to refer them to Saxifrago australis-Trisetetum bertolonii (Saxifragion lingulatae, Potentilletalia caulescentis, Asplenietea trichomanis), a widespread association in the Umbria-Marche Apennine and Central Italy (Giancola and Stanisci 2002).

On sub-vertical calcareous rocky outcrops, large boulders and ledges, we found some peculiar communities characterized by the abundance and dominance of Sedum album. At higher altitudes, above $1650 \mathrm{~m}$ (rel. no. 7-9) these coenoses are characterized by Paronychia kapela, Anthemis cretica subsp. columnae, Sempervivum arachnoideum and Poa molinerii (cluster 8). The floristic composition is dominated by species belonging to Sedo albi-Scleranthetea biennis such as Sedum album, Sempervivum arachnoideum and Petrosedum rupestre together with several transgressive species from dry grasslands of Festuco-Brometea. These coenoses developed on a calcareous substrate have to be attributed to the alliance Alysso alyssoidis-Sedion albi. At the alliance level, the same attribution is valid for the relevès no.10-12 (cluster 6), carried out on large rocky ledges at lower altitudes (ca $1500 \mathrm{~m}$ ) which are physiognomically characterized by the endemic Iris marsica and by Petrosedum rupestre, with the presence of several thermophilous species such as Crupina vulgaris, Lactuca perennis subsp. perennis and Centaurea deusta. The survey no. 13, characterized also by the presence of Iris marsica but with the dominance of Bromopsis erecta, represents the ecotone between the vegetation of the Alysso-Sedion on ledges and the contiguous dry grasslands of Festuco-Brometea, which are developed where the soils are more evolved and deeper. Our current state of knowledge about Alysso-Sedion vegetation in the studied area does not make it possible to find a clear reference to any already described association; therefore these two coenoses are provisionally indicated as Sedum album-Paronychia kapela community and Sedum album-Iris marsica community. 
Calcareous screes and mobile debris have only small surfaces in the study area; they are represented by the relevè no. 14 (cluster 7), carried out at medium altitude $(1480 \mathrm{~m})$, on the scree fed by the characteristic rocky spike present on the right side of the St. Rufo valley, known as Peschio dell'Aquila. This plant community has sparse cover and is characterized by Rumex scutatus, Galium magellense and Scrophularia canina. The scree vegetation of the alpine and subalpine belt in the Central Apennine is quite well known, while at lower altitudes it has rarely been investigated (see Ciaschetti et al. 2020 and references therein). Also in this case, it was not possible to identify a reference at the association level for the Petrosedum rupestre-Rumex scutatus community of the study area. The presence of Galium magellense suggests a probable framework within the alliance Linario-Festucion dimorphae, describing Apennine glareicolous communities of calcareous screes, from the supratemperate to orotemperate thermotypes, even if most of the diagnostic species are lacking. The floristic impoverishment could be justified by the fact that in the study area the most important screes are located at rather low altitudes, at the lower ecological limit of Linario-Festucion dimorphae. In fact, at higher altitude we observed in this habitat also the presence of Drypis spinosa. Although the abundance of Petrosedum rupestre would seem to indicate an affinity with the association Linario purpureae-Petrosedetum rupestris recently described for several localities of the Abruzzo territory (Ciaschetti et al. 2020), the overall floristic composition of the community herein reported is rather different from the one described for Abruzzo and the diagnostic species are absent. In addition, this thermophilic association was referred to a different order and alliance (Scrophulario bicoloris-Helicrhysetalia italici Brullo, 1984, Linarion purpureae Brullo, 1984) within the class Thlaspietea rotundifolii.

\section{Meadows and grasslands}

In the lower part of the study area, at an altitude below $1200 \mathrm{~m}$, small patches of regularly mowed grasslands are still present (cluster 4; rel. no. 15-17), developed on deep, partially terraced, well drained alluvial soil. They are species rich, with 54 species per plot on average. Floristically, the dominant species (Trifolium incarnatum, T. repens, T. pratense, Poa trivialis, Dactylis glomerata, Phleum nodosum, Cynosurus cristatus) are indicators of the class Molinio-Arrhenatheretea, accompanied by several nitrophilous and ruderal species such as Bromus hordeaceus and Dasypyrum villosum. The perennial meso and supratemperate Apennine grasslands, usually grazed and mowed once a year, which develop on mesotrophic soils with good water availability and rich in nutrients, have been commonly attributed to the Cynosurion cristati alliance, (see the Italian review of the alliance in Blasi et al. 2012 and references therein). The classification of Cynosurion grasslands has often been considered to be somewhat problematic (Blasi et al. 2012) due to the fact that exclusive species are lacking and most of the diagnostic species range widely from both a geographical and ecological point of view. Although the surveys carried out in the study area can be referred to Cerastio arvensis-Cynosurenion cristati suballiance, the attribution to an already described association remains unresolved, also be- 
cause the Apennine's associations have not yet been the subject of a critical review which clarifies delimitation and differential species. Probably the closest association could be identified in the Colchico lusitani-Cynosuretum, repeatedly reported on the UmbriaMarche Apennines (e.g. Allegrezza 2003; Biondi et al. 2004; Catorci et al. 2007).

The most widespread vegetation in the study area is represented by the dry grasslands of the Festuco-Brometea class (cluster 5; rel. no. 18-30), mainly used for horse and cattle grazing, which replaced the beech forest vegetation on the mountain slopes. In particular, they can be classified in Phleo ambigui-Brometalia order including xerophilous and semi-mesophilous secondary grasslands of the Central-southern Apennines, that occur from the supramediterranean to the upper supratemperate thermotype. These plant communities have a high physiognomic and floristic diversification in relation to local characteristics of the site (exposure, rockiness, soil depth and $\mathrm{pH}$ ) and to the degree of grazing. The relevès no. 18-22 (cluster 10) are particularly species rich (mean 52 species per releve) and were found at lower altitude (max $1300 \mathrm{~m}$ ), frequently on moraine deposits. They are characterized by a high incidence of chamaephytes (e.g. Helianthemum apenninum, $H$. oelandicum subsp. incanum, $H$. nummularium subsp. obscurum, Thymus longicaulis, T. oenipontanus) and by the presence of several therophytes (e.g. Trifolium campestre, T. scabrum, Euphrasia liburnica). However, they are physiognomically dominated by hemicryptophytes such as Bromopsis erecta, Festuca circummediterranea, Phleum hirsutum subsp. ambiguum. From a phytosociological point of view, the ecology and floristic analysis led to the inclusion of this community in the association Asperulo purpureae-Brometum erecti, frequently reported for the Umbria-Marche Apennine (e.g. Catorci et al. 2007) and described with several variants and subassociations. The releve no. 23 represents a particular stand on strongly inclined slopes at higher altitude $(1500 \mathrm{~m})$ dominated by Bromopsis erecta but with a high cover of Securigera varia and Petrosedum rupestre, which cannot be easily classified at the level of association.

At higher altitude (cluster 9) and on more inclined slopes, in the dry grasslands can be noted the presence of Sesleria nitida and a floristic composition close to the association Seslerio nitidae-Brometum erecti. Near the summit area of the mountain slopes or in eroding areas, the floristic composition becomes impoverished and the spiny chamaephyte Astragalus sempervirens was found as co-dominant with Sesleria nitida. The reference for this community is the Astragalo sempervirenti-Seslerietum nitidae, an association described for the grasslands of the summit sectors of Coscerno and Civitella Mountains in Umbria (Biondi and Ballelli 1995). The parts at higher altitudes of the mountain slopes, relying on calcareous-marly substrata, are occupied by grasslands dominated by Brachypodium genuense. The presence of some acidophilic species (e.g. Luzula campestris, Genista sagittalis, Campanula micrantha) which are frequently found in the vegetation of Nardetea strictae (see Di Pietro et al. 2017 for a review of these communities in the Italian Peninsula), indicates the presence of decarbonated soils with a lower $\mathrm{pH}$. Despite this, the floristic composition is clearly dominated by Festuco-Brometea species; therefore, the reference for these coenoses, is the order Phleo ambigui-Brometalia erecti and the alliance Phleo-Bromion erecti, but unlike the previous ones, in this case the arid high-montane grasslands are to be referred to the sub-alliance Brachypodienion genuensis. At the association level, the floristic analysis led to refer- 
ring this community to the Potentillo rigoanae-Brachypodietum genuensis, an association quite widespread in the Central Apennine, in particular in Lazio and Abruzzo regions (Lucchese et al. 1995).

We did not survey other relevant coenoses that are present with significant extensions but only outside the surveyed area: the mountain acidophilic grasslands of the Nardetea strictae class, present on the northern slopes of Mt. Pozzoni and in the concave morphologies in the high-mountain orotemperate belt and the discontinuous prairies of the steep slopes dominated by Sesleria juncifolia; the latter can be observed on the steep and inaccessible mountain slope surrounding the cliff of Peschio dell'Aquila.

\section{Discussions and conclusions}

The floristic composition of the study area, at the family level, does not significantly differ from the neighboring regional floras (Anzalone et al. 2010; Conti 1998). The percentage of endemics $(6 \%)$ was quite similar to the flora of the nearby Terminillo massif (5.1\%) studied by Montelucci $(1952,1953)$, slightly lower than the flora of Gran Sasso National Park (8.7\%) (Conti and Bartolucci 2016), but perfectly aligned, for example, with the value of Abruzzo National Park (6.5\%) (Conti and Bartolucci 2015). This difference can be due to the fact that the higher elevation of Gran Sasso National Park allows the presence of a large alpine vegetation belt, known to host several endemic taxa. On the contrary, in the study area, Terminillo massif and Abruzzo National Park, the alpine belt is completely absent. In fact, only considering the ipsophilous flora (above $1900 \mathrm{~m}$ a.s.l.), Conti (2004) calculated a rate of $13.2 \%$ of endemics for Central Apennine.

Similarly, from the chorogical point of view, no particular differences were observed with the flora of Terminillo, except for the contingent of Illirian, SE-European and Pontic species, which are slightly more represented in the flora of the Terminillo, probably because the flora of the latter also includes the lower vegetation belts of thermophilous oak forests and mixed deciduous woods, known to be characterized by the presence of numerous eastern species (Blasi et al. 2004).

Based on overall floristic results, the area of the St. Rufo Valley-Mt. Pozzoni can be considered of particular floristic interest, due to the high number of endemic and rare species detected, as recognized also by Lucchese (2018) who incorporated our preliminary data (Del Vico et al. 2014) in his recent, but not yet completed, atlas of the flora of Lazio.

The studied area is also undoubtedly characterized by a high floristic diversity if we consider that the 794 taxa recorded in this study have been found in an area of only 3,4 $\mathrm{km}^{2}$. The relevance of these data can be easily understood by comparing the number of taxa detected in local floras that have a comparable extension. For example, considering the data reported in Pierini et al. (2009), regarding numerous floras from Tuscany, and limiting to those having extension between 2 and $8 \mathrm{~km}^{2}$, only in the flora of Mt. Ferrato a similar number of taxa (800) was found, but within a study area almost double the size $\left(6 \mathrm{~km}^{2}\right)$ (Biagioli et al. 2002). 
Moreover, we have to keep in mind that the studied area has a modest altitude range, relatively few types of lithologies and thus, a limited number of habitats. Despite this, the vegetation analysis revealed the presence of varied and species rich plant communities, with 311 taxa detected in only 30 relevès. As expected, the higher number of vegetation types was found within the secondary habitats of mountain pastures and dry grasslands. Particularly interesting is the plant community with Iris marsica (referred to the Alysso-Sedion alliance), which indicates, probably for the first time, as limestone mountain ledges can represent a primary habitat for this species endemic of the Central Apennine.

Almost all the plant communities identified here are referable to habitats listed by the Habitat Directive (habitat codes: 6110, 6210, 6520, 8120, 8210, 9210), some of them with priority status $(6110,6210,9210)$, thus their presence would have required the proposal of a Natura 2000 site according to the Habitat Directive (European Union 1992).

The intriguing aspects of this territory combined with, until recently, the complete lack of detailed botanical knowledge, led, in 2016, the Italian Botanical Society to carry out, in the Cittareale municipality, an annual field trip of the working group for Floristics, Systematics and Evolution. During the field trip, with the participation of some of the authors, several other additional localities (e.g. Mt. Boragine $1824 \mathrm{~m}$ a.s.l.), surrounding those herein investigated, were explored floristically (Bartolucci et al. 2019).

The very limited number of alien species identified, none of which is considered invasive, can be considered an indicator of the fairly good state of conservation of the territory in which a completely traditional land use still persists. However, reforested areas, planted with several non- native conifers, are now composed of mature trees able to produce seeds. Recruitment from these could involve a process of spontaneization of non-native coniferous as frequently observed in other territories of Central Apennine, involving, for example, the spread of Pinus nigra. Moreover, the presence of Abies cephalonica and Picea abies in reforested areas could also lead to spontaneization of these species in Lazio, as already observed in the neighboring Abruzzo region (Galasso et al. 2018).

Taking into account how important updating distribution data is, for example for the Red List assessment (Orsenigo et al. 2020), it is certainly possible to affirm that this study constitutes a valid contribution towards filling the gap in our botanical knowledge of a sector of the Central Apennines of high conservation interest.

\section{Syntaxonomic scheme}

\section{ASPLENIETEA TRICHOMANIS (Br.-Bl. in Meier \& Br.-Bl., 1934) Oberdorfer, 1977}

POTENTILLETALIA CAULESCENTIS Br--Bl. in Br.-Bl. \& Jenny, 1926

Saxifragion australis Biondi \& Ballelli ex Brullo 1984

Saxifrago-Trisetetum villosi Biondi \& Ballelli, 1982 


\section{THLASPIETEA ROTUNDIFOLII Br.-B1., 1948}

THLASPIETALIA STYLOSI Avena \& Bruno, 1975

Linarion purpureae Brullo, 1984

Petrosedum rupestre-Rumex scutatus community

\section{SEDO ALBI-SCLERANTHETEA BIENNIS Br.-B1,. 1955}

ALYSSO ALYSSOIDIS-SEDETALIA ALBI Moravec, 1967

Alysso alyssoidis-Sedion albi Oberdorfer \& Müller in Müller 1961

Sedum album-Paronychia kapela community

Sedum album-Iris marsica community

FESTUCO VALESIACAE-BROMETEA ERECTI Br.-BI. \& Tüxen ex Br.-Bl. 1949 PHLEO AMBIGUI-BROMETALIA ERECTI Biondi, Allegrezza, Blasi \& Galdenzi in Biondi, Allegrezza, Casavecchia, Galdenzi, Gasparri, Pesaresi, Vagge and Blasi 2014 Phleo ambigui-Bromion erecti Biondi, Ballelli, Allegrezza \& Zuccarello ex Biondi and

Galdenzi 2012

Phleo ambigui-Bromenion erecti Biondi, Allegrezza \& Zuccarello ex Di Pietro 2011 Asperulo purpureae-Brometum erecti Biondi \& Ballelli ex Di Pietro 2011

Seslerio nitidae-Brometum erecti Bruno \& Covarelli, 1968

Astragalo sempervirentis-Seslerietum nitidae Biondi \& Ballelli, 1995

Brachypodienion genuensis Biondi, Ballelli, Allegrezza \& Zuccarello ex Biondi and Galdenzi 2012

Potentillo rigoanae-Brachypodietum genuensis Lucchese et al., 1995

MOLINIO-ARRHENATHERETEA Tüxen, 1937

TRIFOLIO REPENTIS-PHLEETALIA PRATENSIS Passarge, 1969

Cynosurion cristati Tüxen, 1947

Cerastio arvensis-Cynosurenion cristati Blasi et al., 2012

Trifolium incarnatum-Cynosurus cristatus community

\section{RHAMNO CATHARTICAE-PRUNETEA SPINOSAE Rivas Goday \& Borja ex} Tüxen 1962

PRUNETALIA SPINOSAE Tüxen, 1952

Berberidion vulgaris Br.-Bl., 1950

Rhamno alpinae-Amelanchieretum ovalis Pedrotti, 1994

QUERCO ROBORIS-FAGETEA SYLVATICAE Br.-Bl. \& Vlieger in Vlieger 1937 FAGETALIA SYLVATICAE Pawłowski in Pawłowski, Sokołowski and Wallisch 1928 Aremonio agrimonioidis-Fagion sylvaticae (Horvat) Borhidi in Török, Podani and Borhidi 1989

Lathyro veneti-Fagetum sylvaticae Biondi et al. ex Biondi, Casavecchia, Pinzi, Allegrezza and Baldoni in Biondi, Allegrezza, Casavecchia, Galdenzi, Gigante and Pesaresi 2013 


\section{Acknowledgement}

The authors wish to thank Emidio Gentile and his family, for the kind and warm hospitality at "Lu Ceppe" farmhouse (Cittareale) during the intense survey sessions. Heartfelt thanks to those who accompanied us over these years during the floristic research excursions on the mountain trail: Laura Facioni, Mattia Martin Azzella, Daniela Smiraglia, Fabrizio Muzzi, Goffredo Filibeck, Dario and Alberto Rosati, Martina and Samuele Marignani. We sincerely wish to thank Anna Scoppola and Nicholas Jense for their careful revision and useful improvements to the first version of the manuscript.

\section{References}

Allegrezza M (2003) Vegetazione e paesaggio vegetale della dorsale del Monte San Vicino (Appennino centrale). Fitosociologia 40, Suppl. 1: 3-118. http://www.scienzadellavegetazione.it/sisv/rivista/articoloCerca.do?idArticolo=171

Anzalone B (1951) Contributo alla flora della Montagna della Duchessa (Catena del Monte Velino). Ann. Bot. (Roma) 23(1): 21-30.

Anzalone B, Iberite M, Lattanzi E (2010) La flora vascolare del Lazio. Informatore Botanico Italiano 42(1): 187-317.

APG IV (2016) An update of the Angiosperm Phylogeny Group classification for the orders and families of flowering plants: APG IV. Botanical Journal of the Linnean Society 181(1): 1-20. https://doi.org/10.1111/boj.12385

Argenti P, Kotsakis T, Sabatini F (2008) Myotis dasycneme in a latest pleistocene bat assemblage of Cittareale cave (Rieti, Latium, Central Italy). Geologica Romana 41: 117-123.

Ballelli S (2003) Aggiornamento delle conoscenze sulla Flora dell'Umbria. Webbia 58(1): 1-55. https://doi.org/10.1080/00837792.2003.10670743

Bartolucci F, Ranalli N, Bouvet D, Cancellieri L, Fortini P, Gestri G, Di Pietro R, Lattanzi E, Lavezzo P, Longo D, Marsili S, Peccenini S, Peruzzi L, Salerno G, Soldano A, Tilia A, Turcato C, Viciani D, Wagensommer RP, Conti F (2012) Contributo alla conoscenza floristica del settore settentrionale del Gran Sasso d'Italia (Parco Nazionale del Gran Sasso e Monti della Laga) (Abruzzo): Resoconto dell'escursione del Gruppo di Floristica (S.B.I.) nel 2010. Informatore Botanico Italiano 44(2): 355-385.

Bartolucci F, Peruzzi L, Galasso G, Albano A, Alessandrini A, Ardenghi NMG, Astuti G, Bacchetta G, Ballelli S, Banfi E, Barberis G, Bernardo L, Bouvet D, Bovio M, Cecchi L, Di Pietro R, Domina G, Fascetti S, Fenu G, Festi F, Foggi B, Gallo L, Gottschlich G, Gubellini L, Iamonico D, Iberite M, Jiménez-Mejías P, Lattanzi E, Marchetti D, Martinetto E, Masin RR, Medagli P, Passalacqua NG, Peccenini S, Pennesi R, Pierini B, Poldini L, Prosser F, Raimondo FM, Roma-Marzio F, Rosati L, Santangelo A, Scoppola A, Scortegagna S, Selvaggi A, Selvi F, Soldano A, Stinca A, Wagensommer RP, Wilhalm T, Conti F (2018) An updated checklist of the vascular flora native to Italy. Plant Biosystems 152(2): 179-303. https://doi.org/10.1080/11263504.2017.1419996

Bartolucci F, Cancellieri L, Conti F, Banfi E, Bouvet D, Celestini M, Ciaschetti G, Di Pietro R, Falcinelli F, Fascetti S, Galasso G, Lattanzi E, Masin RR, Pennesi R, Rosati L, Stinca A, 
Tilia A, Forte TGW, Scoppola A (2019) Contribution to the floristic knowledge of Velino and Aterno valleys (Lazio-Abruzzo, central Italy). Italian Botanist 7: 93-100. https://doi. org/10.3897/italianbotanist.7.34697

Biagioli M, Gestri G, Acciai B, Messina A (2002) Fiori sulla pietra. Flora vascolare illustrata delle ofioliti e delle altre terre del Monteferrato in Toscana. Gramma, Perugia.

Biondi E, Ballelli S (1995) Le praterie del Monte Coscerno e Monte Civitella (Appennino umbro-marchigiano - Italia centrale). Fitosociologia 30: 91-121.

Biondi E, Pinzi M, Gubellini L (2004) Vegetazione e paesaggio vegetale del massiccio del Monte Cucco (Appennino centrale, dorsale umbro-marchigiana). Fitosociologia 41(suppl.1): 3-81.

Biondi E, Blasi C, Allegrezza M, Anzellotti I, Azzella MM, Carli E, Casavecchia S, Copiz R, Del Vico E, Facioni L, Galdenzi D, Gasparri R, Lasen C, Pesaresi S, Poldini L, Sburlino G, Taffetani F, Vagge I, Zitti S, Zivkovic L (2014) Plant communities of Italy: The Vegetation Prodrome. Plant Biosystems 148(4): 728-814. https://doi.org/10.1080/11263504.2014. 948527

Blasi C, Di Pietro R, Filesi L (2004) Syntaxonomical revision of Quercetalia pubescenti-petraeae in the Italian Peninsula. Fitosoc 41: 87-164.

Blasi C, Marignani M, Copiz R, Fipaldini M, Bonacquisti S, Del Vico E, Rosati L, Zavattero L (2009) Carta delle Aree Importanti per le Piante (IPAs) in Italia. Palombi editori, Roma ISBN 978-88-6060-272-5. CD allegato. In: Blasi C, Marignani M, Copiz R, Fipaldini M (Eds) Cartografia delle Aree Importanti per le Piante in Italia. Palombi editori, Roma.

Blasi C, Di Pietro C, Filibeck G, Filesi L, Ercole S, Rosati L (2010) Le Serie di Vegetazione della Regione Lazio. In: BLASI C. La Vegetazione d'Italia. Palombi \& partner S.r.l., Roma, 281-310.

Blasi C, Marignani M, Copiz R, Fipaldini M, Bonacquisti S, Del Vico E, Rosati L, Zavattero L (2011) Important Plant Areas in Italy: From data to mapping. Biological Conservation 144(1): 220-226. https://doi.org/10.1016/j.biocon.2010.08.019

Blasi C, Tilia A, Rosati L, Del Vico E, Copiz R, Ciaschetti G, Burrascano S (2012) Geographical and ecological differentiation in Italian mesophilous pastures referred to the alliance Cynosurion cristati Tx. 1947. Phytocoenologia 41(4): 217-229. https://doi.org/10.1127/0340269X/2011/0041-0504

Braun-Blanquet J (1965) Plant sociology. The study of plant community. Hafner Publishing Company, New York and London.

Calamita F, Pizzi A, Romano A, Roscioni M, Scisciani V, Vecchioni G (1995) La tettonica quaternaria nella dorsale appenninica umbro-marchigiana: Una deformazione progressiva non coassiale. Studi Geol. Camerti, vol. Spec. 1995(1): 201-224.

Cancellieri L, Sperandii MG, Filibeck G (2017) First record of the steppic relict Astragalus exscapus L. subsp. exscapus in the Apennines (Abruzzo, Italy), and biogeographic implications. Plant Biosystems 151(6): 944-948. https://doi.org/10.1080/11263504.2017.1311963

Catorci A, Gatti R, Ballelli S (2007) Studio fitosociologico della vegetazione delle praterie montane dell'Appennino maceratese (Italia centrale). Braun-Blanquetia 42: 101-143.

Ciaschetti G, Di Musciano M, Pirone G, Di Cecco V, Pace L, Frattaroli A (2020) A new pioneer association of detrital substrata of the hilly and low-mountain belts in Central Apennines (Italy). Plant Sociology 57(1): 75-84. https://doi.org/10.3897/pls2020571/08 Conti F (1998) An annotated check-list of the flora of the Abruzzo. Bocconea 10: e276. 
Conti F (2004) La flora ipsofila dell'Appennino centrale: Ricchezza ed endemiti. Informatore Botanico Italiano 35(2): 383-386.

Conti F, Bartolucci F (2015) The Vascular Flora of the National Park of Abruzzo, Lazio and Molise (Central Italy). Springer International Publishing, Cham. https://doi. org/10.1007/978-3-319-09701-5

Conti F, Bartolucci F (2016) The vascular flora of Gran Sasso and Monti della Laga National Park (Central Italy). https://doi.org/10.11646/phytotaxa.256.1.1

Conti F, Manzi A, Pedrotti F (1992) Libro rosso delle Piante d'Italia. Ministero Ambiente, WWF Italia, Società Botanica Italiana, Roma, 637 pp.

Conti FA, Manzi A, Pedrotti F (1997) Liste Rosse Regionali delle Piante d'Italia. WWF Italia, Società Botanica Italiana, CIAS, Univ. Camerino, $139 \mathrm{pp}$.

Conti F, Abbate G, Alessandrini A, Blasi C [Eds] (2005) An annotated checklist of the Italian vascular flora. Palombi Editori, Roma.

Conti F, Falcinelli F, Palermo D, Paolucci M, Paris P, Domina G, Manzi A, Gallo L, Tondi G, Pennesi R, Donnini D, Bartolucci F (2018) Additions to the vascular flora of central Italy. Second contribution. Natural History Sciences : Atti della Societa Italiana di Scienze Naturali e del Museo Civico di Storia Naturale in Milano 5(1): 59-70. https://doi.org/10.4081/ nhs. 2018.378

Conti F, Ciaschetti G, Di Martino L, Bartolucci F (2019) An annotated checklist of the vascular flora of Majella National Park (Central Italy). Phytotaxa 412(1): 1-90. https://doi. org/10.11646/phytotaxa.412.1.1

Crugnola G (1900) Materiali per la flora dell'Abruzzo teramano. Un secondo manipolo di piante del Gran Sasso d'Italia. Nuovo Giornale Botanico Italiano 7: 233-247.

Cutini M, Stanisci A, Pirone G (2002) L'alleanza Berberidion vulgaris in Appennino centrale (Italia centrale). Fitosociologia 39(2): 31-50.

Del Vico E, Lattanzi E, Marignani M, Rosati L (2014) Specie rare e di interesse conservazionistico di un settore poco conosciuto dell'Appennino centrale (Cittareale, Rieti). In: Peruzzi L, Domina G (Eds) Riunione scientifica del Gruppo per la Floristica, Sistematica ed Evoluzione, Società Botanica Italiana, 21-22/11/2014. Società Botanica Italiana, Roma, 33-34.

Di Pietro R, Tondi G, Minutillo F, Bartolucci F, Tinti D, Cecchetti F, Conti F (2008) Ulteriore contributo alla conoscenza della flora vascolare dei Monti della Laga (Appennino centrale). Webbia 63(1): 55-67. https://doi.org/10.1080/00837792.2008.10670833

Di Pietro R, Terzi M, Fortini P (2017) A revision of the high-altitude acidophilous and chionophilous grasslands of the Apennines (Peninsular Italy), a long-lasting intricate syntaxonomic issue. Phytocoenologia 47(3): 261-304. https://doi.org/10.1127/phyto/2017/0162

European Union (1992) Council Directive 92/43/EEC of 21 may 1992 on the conservation of natural habitats and of wild fauna and flora. https://eur-lex.europa.eu/legal-content/EN/ TXT/?uri=celex\%3A31992L0043 [accessed 2020-04-15]

Falcinelli F, Conti F, Donnini D (2016) Secondo contributo alla flora vascolare dell'Umbria (Italia centrale). Natural History Sciences : Atti della Societa Italiana di Scienze Naturali e del Museo Civico di Storia Naturale in Milano 3(1): 21-26. https://doi.org/10.4081/nhs.2016.273

Filibeck G, Cancellieri L, Bartolucci F, Becker U, Conti F, Maestri S, Mürz M, Schommer E, Sperandii MG, Becker T (2020) Festuca valesiaca Schleich. ex Gaudin newly discovered in 
the Central Apennines (Italy): A further example of steppe relict in the Abruzzo "dry valleys.”. Plant Biosystems 154(5): 593-600. https://doi.org/10.1080/11263504.2019.1651784

Galasso G, Conti F, Peruzzi L, Ardenghi NMG, Banfi E, Celesti-Grapow L, Albano A, Alessandrini A, Bacchetta G, Ballelli S, Bandini Mazzanti M, Barberis G, Bernardo L, Blasi C, Bouvet D, Bovio M, Cecchi L, Del Guacchio E, Domina G, Fascetti S, Gallo L, Gubellini L, Guiggi A, Iamonico D, Iberite M, Jiménez-Mejías P, Lattanzi E, Marchetti D, Martinetto E, Masin RR, Medagli P, Passalacqua NG, Peccenini S, Pennesi R, Pierini B, Podda L, Poldini L, Prosser F, Raimondo FM, Roma-Marzio F, Rosati L, Santangelo A, Scoppola A, Scortegagna S, Selvaggi A, Selvi F, Soldano A, Stinca A, Wagensommer RP, Wilhalm T, Bartolucci F (2018) An updated checklist of the vascular flora alien to Italy. Plant Biosystems 152(3): 556-592. https://doi.org/10.1080/11263504.2018.1441197

Gatti C, Uffreduzzi T (1989) Giù nella grotta. Falacrina 1: 8-9.

Giancola C, Stanisci A (2002) La vegetazione delle rupi di altitudine del Molise. Fitosociologia 39(2): 31-50.

Grande L (1904) Primo contributo alla Flora di Villavallelonga nella Marsica. Nuovo Giorn Bot Ital 11(2): 125-140.

Gravina P (1812) Giornale della peregrinazione Botanica eseguita nelle Montagne del Circondario di Scanno, dal Sig. Pasquale Gravina. Giornale Enciclopedico di Napoli 6: 3-49.

Gubellini L, Hofmann N, Pinzi M (2014) Contributo alla conoscenza della flora vascolare delle Marche e di alcune regioni limitrofe. Informatore Botanico Italiano 46: 17-26.

Hortal J, de Bello F, Diniz-Filho JAF, Lewinsohn TM, Lobo JM, Ladle RJ (2015) Seven Shortfalls that Beset Large-Scale Knowledge of Biodiversity. Annual Review of Ecology Evolution and Systematics 46(1): 523-549. https://doi.org/10.1146/annurev-ecolsys-112414-054400

Iocchi M, Bartolucci F, Carotenuto L, Valfrè D, Cutini M, Theurillat JP (2010) Note floristiche per la Riserva Naturale Regionale delle "Montagne della Duchessa” (Lazio nord-orientale). Informatore Botanico Italiano 42(2): 503-508.

Lucchese F (2018) Atlante della Flora Vascolare del Lazio, cartografia, ecologia e biogeografia (Vol. 2). La flora di maggiore interesse conservazionistico. Regione Lazio, Direzione Capitale Naturale, Parchi e Aree Protette, Roma, 400 pp.

Lucchese F, Persia G, Pignatti S (1995) I Prati a Bromus erectus Hudson dell'Appennino Laziale. Fitosociologia 30: 145-180.

Montelucci G (1952) La vegetazione del M. Terminillo (Appennino centrale). Webbia 8(2): 245-379. https://doi.org/10.1080/00837792.1952.10669603

Montelucci G (1953) La vegetazione del M. Terminillo (Appennino Centrale): Continuazione. Webbia 9(1): 49-354. https://doi.org/10.1080/00837792.1953.10669614

Orsenigo S, Fenu G, Gargano D, Montagnani C, Abeli T, Alessandrini A, Bacchetta G, Bartolucci F, Carta A, Castello M, et al. (2020) Red list of threatened vascular plants in Italy. Plant Biosystems: 1-26. https://doi.org/10.1080/11263504.2020.1739165

Paolucci L (1891) Flora Marchigiana. Tip. Federici, Pesaro, 656 pp.

Pedrotti F (1994) Associazioni dell'ordine Prunetalia dell'Appennino centrale. Guida all'Escursione della Società Italiana di Fitosociologia in Trentino (1-5 luglio 1994). Dip.to di Botanica ed Ecologia, Università di Camerino, 146-148. 
Pesaresi S, Biondi E, Casavecchia S (2017) Bioclimates of Italy. Journal of Maps 13(2): 955960. https://doi.org/10.1080/17445647.2017.1413017

Pierini B, Garbari F, Peruzzi L (2009) Flora vascolare del Monte Pisano (Toscana nord-occidentale). Informatore Botanico Italiano 41(2): 147-213.

Pignatti S (1982) Flora d'Italia. Edagricole, Bologna.

Rivas-Martínez S, Rivas-Saenz S, Penas A (2011) Worldwide Bioclimatic classification system. Glob. Geobot. 1: 1-634.

Rosati L, Fascetti S, Romano VA, Potenza G, Lapenna MR, Capano A, Nicoletti P, Farris E, de Lange PJ, Del Vico E, Facioni L, Fanfarillo E, Lattanzi E, Cano-Ortiz A, Marignani M, Fogu MC, Bazzato E, Lallai E, Laface VLA, Musarella CM, Spampinato G, Mei G, Misano G, Salerno G, Esposito A, Stinca A (2020) New Chorological Data for the Italian Vascular Flora. Diversity (Basel) 12(1): 1-22. https://doi.org/10.3390/d12010022

Rossi G, Montagnani C, Gargano D, Peruzzi L, Abeli T, Ravera S, Cogoni A, Fenu G, Magrini S, Gennai M, et al. [Eds] (2013) Lista Rossa della Flora Italiana. 1. Policy Species e altre specie minacciate. Comitato Italiano IUCN e Ministero dell'Ambiente e della Tutela del Territorio e del Mare.

Scoppola A, Blasi C [Eds] (2005) Stato delle conoscenze sulla flora vascolare d'Italia. Palombi Editori. Roma.

Tenore M (1830) Succinta relazione del viaggio fatto in Abruzzo ed in alcune parti dello Stato Pontificio dal Cavalier Tenore nell'Esta` del 1829. Stamperia della Societa` Filomatica: [1]-90 [91]. Tondi G, Di Pietro R, Ballelli S, Minutillo F (2003) New contribution to the knowledge of the flora of the Laga Mountains (Central Apennines). Webbia 58(1): 57-76. https://doi.org/1 0.1080/00837792.2003.10670744

Tutin TG, Heywood VH, Burges NA, Moore DM, Valentine DH, Walters SM, Webb DA [Eds] (1968) Flora Europaea (Vol. 2). Cambridge University Press, Cambridge, 465 pp.

Tutin TG, Heywood VH, Burges NA, Moore DM, Valentine DH, Walters SM, Webb DA [Eds] (1972) Flora Europaea (Vol. 3). Cambridge University Press, Cambridge, 381 pp. https://doi.org/10.2307/1218149

Tutin TG, Heywood VH, Burges NA, Moore DM, Valentine DH, Walters SM, Webb DA [Eds] (1976) Flora Europaea (Vol. 4). Cambridge University Press, Cambridge, 515 pp.

Tutin TG, Heywood VH, Burges NA, Moore DM, Valentine DH, Walters SM, Webb DA [Eds] (1980) Flora Europaea (Vol. 5). Cambridge University Press, Cambridge, 463 pp.

Tutin TG, Burges NA, Chater AO, Edmondson JR, Heywood VH, Moore DM, Valentine DH, Walters SM, Webb DA [Eds] (1993) Flora Europaea (Vol. 1). Second edition. Cambridge University Press, Cambridge, 581 pp.

Venanzoni R (1992) I prati umidi e inondati dell'alta valle del Velino (Rieti - Italia centrale). Doc. Phytosoc. 14: 149-164.

Zodda G (1931) Prime notizie sulla Flora delle Mainarde. Ann Bot (Roma) 19: 163-201.

Zodda G (1954) La Flora Teramana. Webbia 10(1): 1-317. https://doi.org/10.1080/0083779 2.1954.10669624 


\section{Appendix I}

Floristic list of detected taxa in the study area. $\mathrm{E}=$ endemic taxon of Italian territory; R, MR, RR = increasing level of rarity, form rare to very rare in the regional flora of Lazio coded as in Anzalone et al. (2010). Floristic novelties for the regional flora are marked with asterisk. CULT = taxon detected only as cultivated. NAT $=$ alien taxon naturalized in the study area.

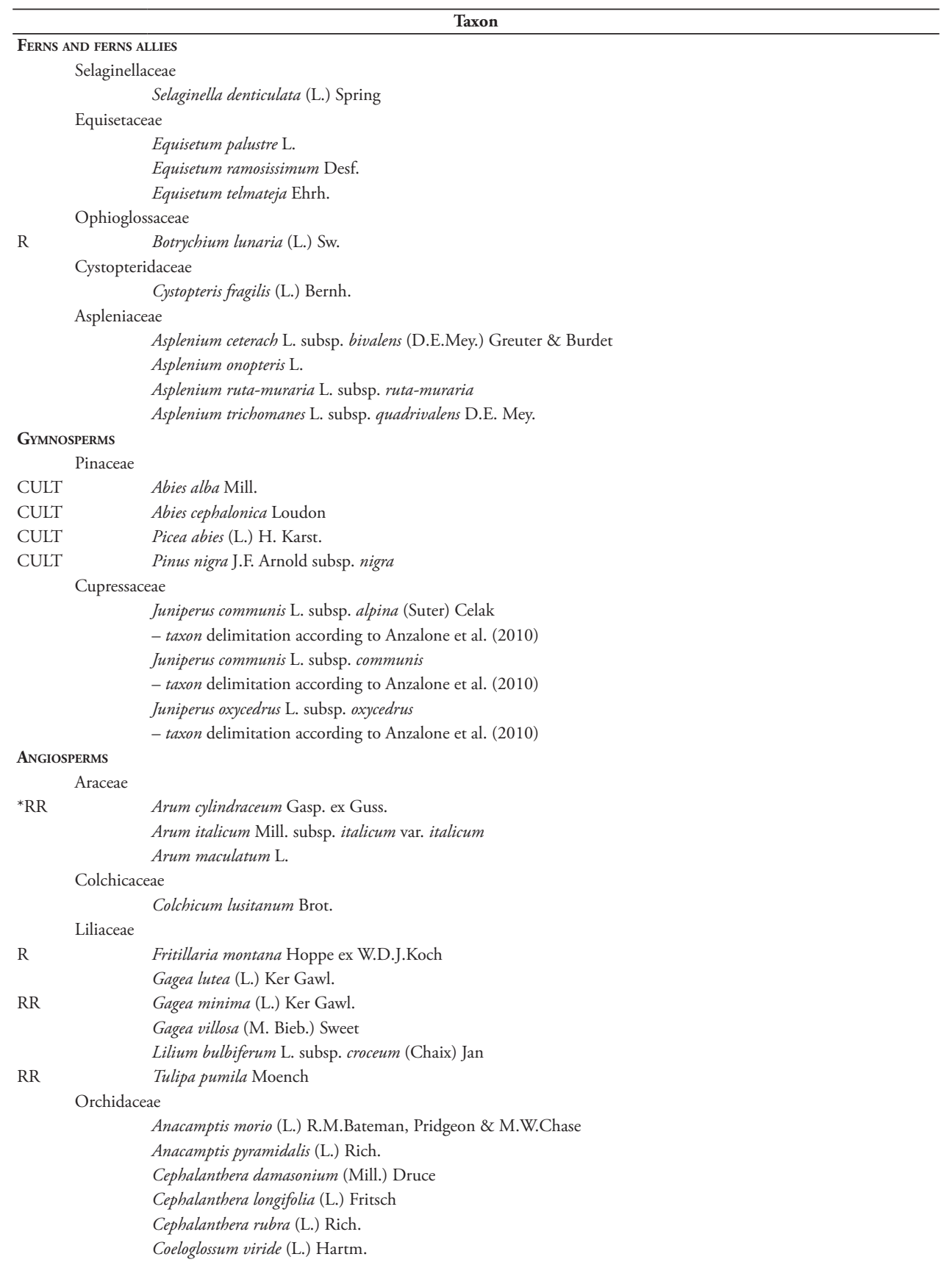




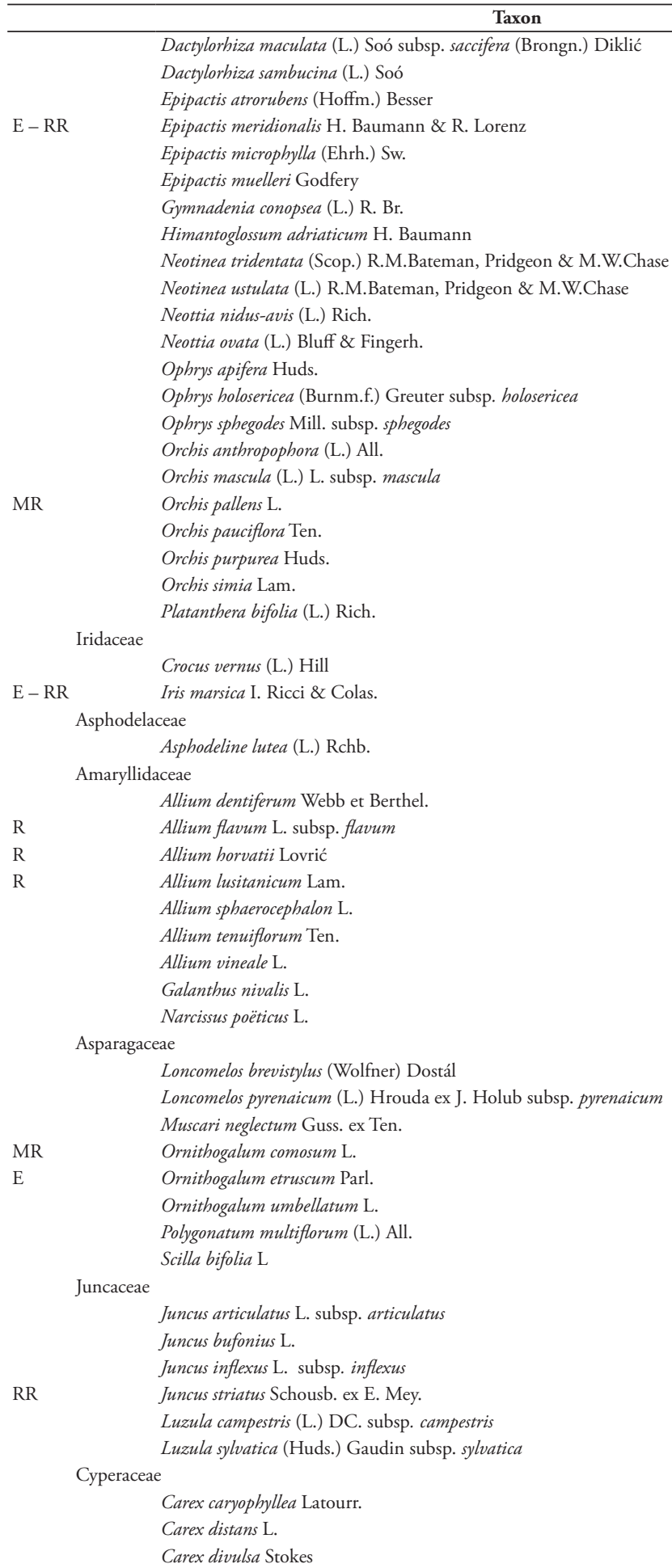




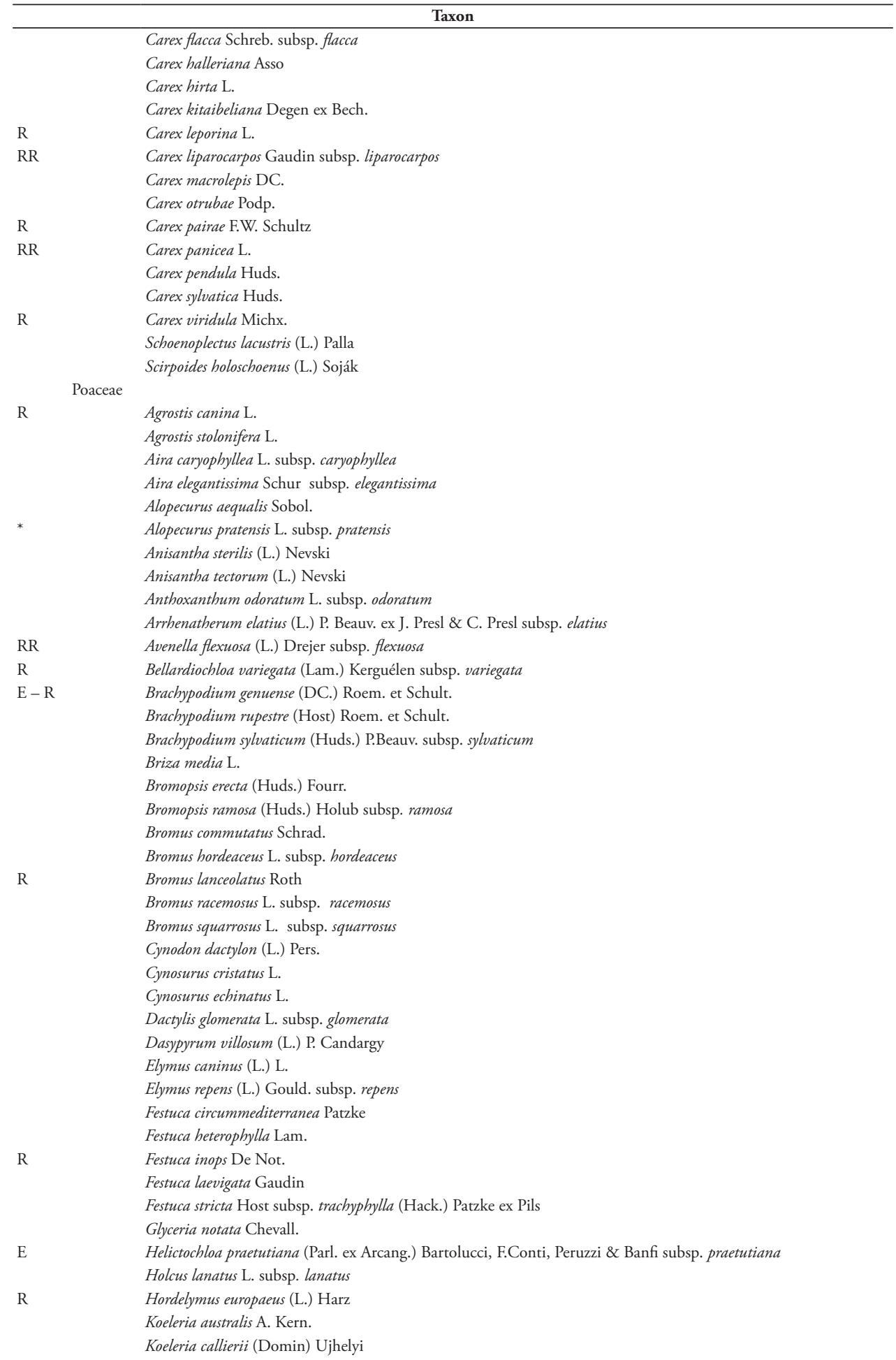




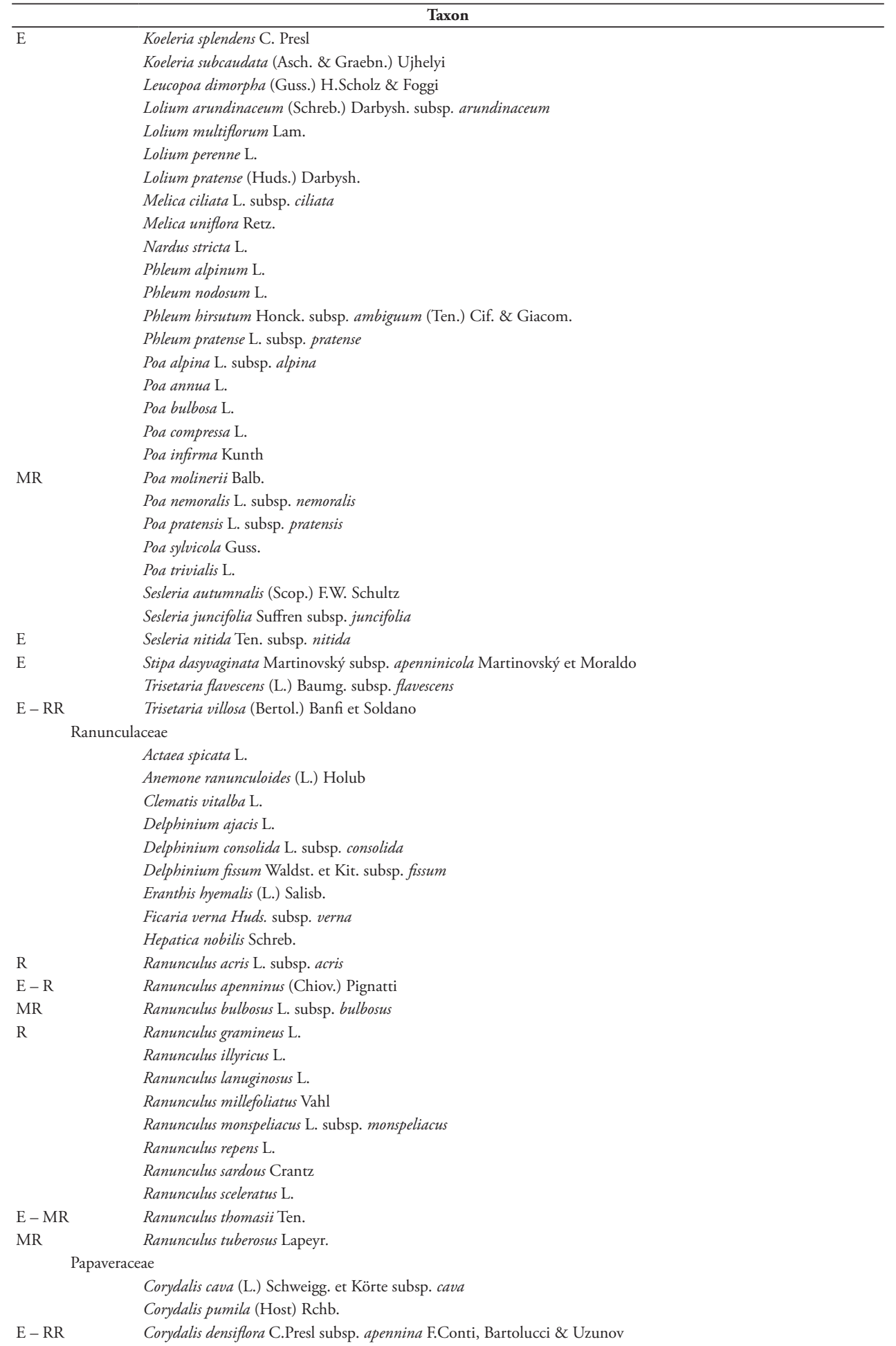


Taxon

Papaver dubium L. subsp. dubium

Papaver rhoeas L. subsp. rhoeas

Crassulaceae

Petrosedum rupestre (L.) P.V.Heath

Sedum acre $\mathrm{L}$.

Sedum album $\mathrm{L}$.

$\mathrm{R}$

Sedum atratum L. subsp. atratum

Sedum dasyphyllum $\mathrm{L}$.

Sedum hispanicum $\mathrm{L}$.

Sedum rubens $\mathrm{L}$.

Sedum sexangulare $\mathrm{L}$.

Sempervivum arachnoideum $\mathrm{L}$.

E

Sempervivum riccii Iberite et Anzal.

Grossulariaceae

$\mathrm{R}$

Ribes alpinum $\mathrm{L}$.

MR Ribes multiflorum Kit. ex Roem. et Schult. subsp. multiflorum

$\mathrm{R} \quad$ Ribes uva-crispa L. subsp. uva-crispa

Saxifragaceae

Saxifraga adscendens L. subsp. adscendens

Saxifraga bulbifera $\mathrm{L}$.

$\mathrm{R}$

Saxifraga callosa Sm. subsp. callosa

E-R Saxifraga exarata Vill. subsp. ampullacea (Ten.) D.A.Webb

Saxifraga granulata L. subsp. granulata

Saxifraga paniculata Mill.

E

Saxifraga porophylla Bertol. subsp. porophylla

Saxifraga rotundifolia L. subsp. rotundifolia

Saxifraga tridactylites $\mathrm{L}$.

Fabaceae

Anthyllis montana L. subsp. jacquinii (Rchb.f.) Rohlena

$\mathrm{R}$

Anthyllis vulneraria L. subsp. pulchella (Vis.) Bornm.

Anthyllis vulneraria L. subsp. rubriflora (DC.) Arcang.

Astragalus depressus L. subsp. depressus

Astragalus glycyphyllos L.

$\mathrm{R} \quad$ Astragalus sempervirens Lam.

E - MR Astragalus sirinicus Ten.

Colutea arborescens $\mathrm{L}$.

Coronilla minima L. subsp. minima

Coronilla scorpioides (L.) W.D.J. Koch

Cytisophyllum sessilifolium (L.) O. Lang

Cytisus hirsutus $\mathrm{L}$.

Lotus herbaceus (Vill.) Jauzein

RR

Genista sagittalis L.

Genista tinctoria L.

Hippocrepis comosa L. subsp. comosa

MR

Hippocrepis glauca Ten.

Lathyrus cicera $\mathrm{L}$.

Lathyrus latifolius L.

Lathyrus nissolia L.

Lathyrus pratensis L. subsp. pratensis

Lathyrus sphaericus Retz.

Lathyrus sylvestris L. subsp. sylvestris

Lathyrus venetus (Mill.) Wohlf.

Lathyrus vernus (L.) Bernh.

MR Lotus corniculatus L. subsp. alpinus (DC.) Rothm.

Lotus corniculatus L. subsp. corniculatus

Medicago falcata L. subsp. falcata

Medicago lupulina $\mathrm{L}$. 


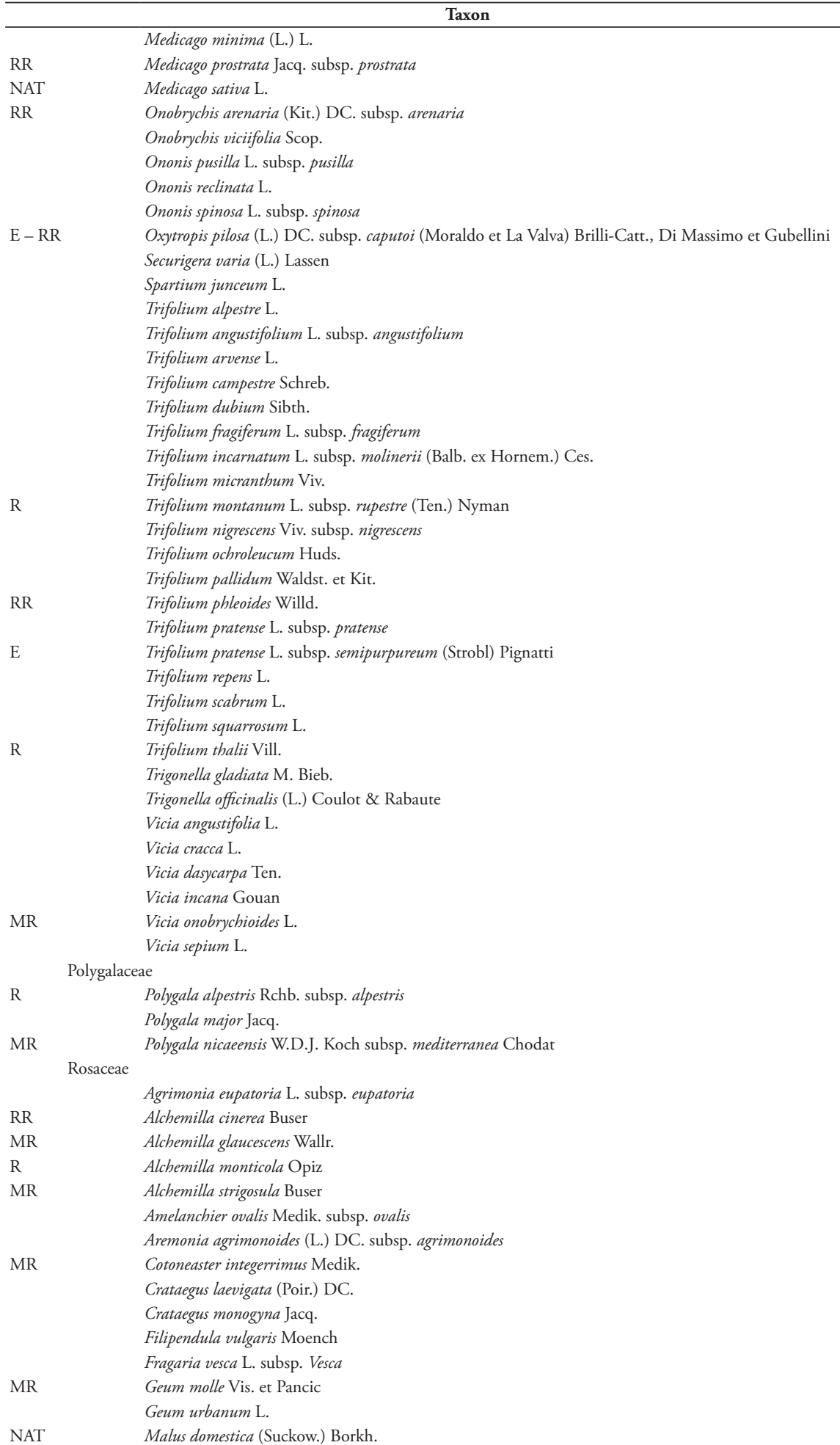


Taxon

$\mathrm{R}$

Urticaceae

Fagaceae

Fagus sylvatica L. subsp. sylvatica

Quercus cerris $\mathrm{L}$.

Quercus pubescens Willd. subsp. pubescens

Betulaceae

Corylus avellana $\mathrm{L}$.

Ostrya carpinifolia Scop.

Cucurbitaceae

Malus sylvestris (L.) Mill.

Potentilla pedata Willd ex

Potentilla recta L.subsp. recta

Potentilla reptans $\mathrm{L}$.

Poterium sanguisorba subsp. balearicum (Bourg. ex Nyman) Stace

Prunus avium (L.) L.

Prunus mahaleb $\mathrm{L}$

Prunus spinosa L. subsp. spinosa

Pyrus communis L. subsp. pyraster (L.) Ehrh.

Rosa canina L. s.s.

Rosa corymbifera Borkh

ontana Chaix

Rosa spinosissima $\mathrm{L}$.

Rosa squarrosa (A. Rau) Boreau

Rubus caesius $\mathrm{L}$

Rubus canescens DC.

Rubus hirtus Waldst. et Kit.

Rubus idaeus L. subsp. idaeus

Rubus ulmifolius Schott

Sorbus aria (L.) Crantz

Atadinus alpinus (L.) Raf.

Atadinus fallax (Boiss.) Hauenschild

Atadinus pumilus (Turra) Hauenschild subsp. pumilus

Rhamnus saxatilis Jacq.

Bryonia dioica Jacq.

Celastraceae

Euonymus europaeus L.

Euonymus latifolius (L.) Mill.

RR

Parnassia palustris L. subsp. palustris

Violaceae

Viola alba Besser subsp. dehnhardtii (Ten.) W.Becker

Viola arvensis Murray

Viola engeniae Parl. subsp. eugeniae

MR

Viola kitaibeliana Schult.

Viola odorata L.

Viola reichenbachiana Jord. ex Boreau

Salicaceae

Populus tremula $\mathrm{L}$.

Salix apennina A.K. Skortsov

Salix caprea $\mathrm{L}$. 


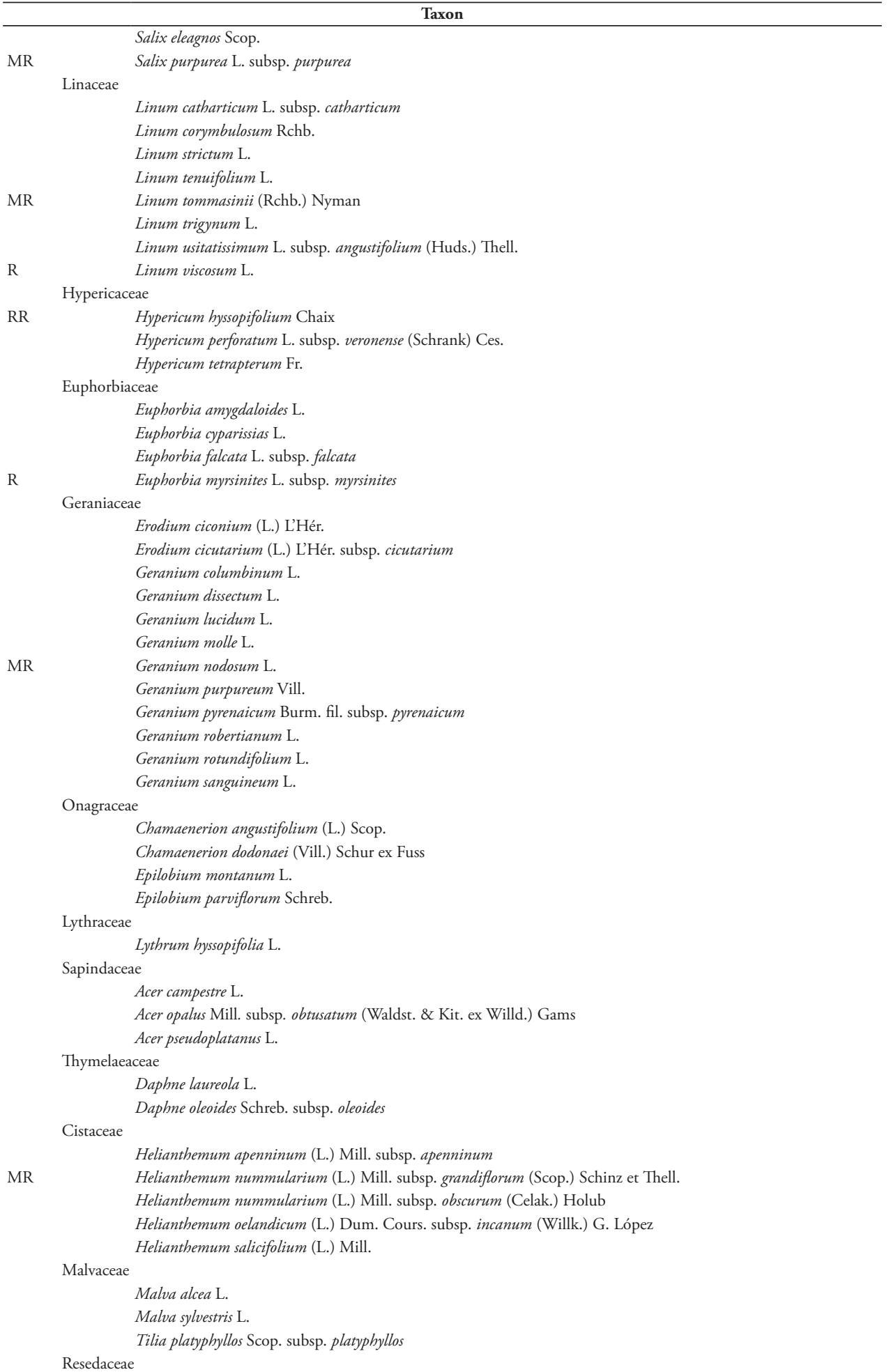


Taxon

Reseda luteola $\mathrm{L}$.

Brassicaceae

Aethionema saxatile (L.) R.Br.

Alliaria petiolata (M. Bieb.) Cavara et Grande

Alyssum alyssoides (L.) L.

Alyssum simplex Rudolphi

Arabidopsis thaliana (L.) Heynh.

Arabis alpina L. subsp. caucasica (Willd.) Briq.

$\mathrm{RR}$

Arabis auriculata Lam.

Arabis collina Ten. subsp. collina

Arabis hirsuta (L.) Scop.

Arabis sagittata (Bertol.) DC.

Barbarea bracteosa Guss.

Barbarea vulgaris $\mathrm{R}$. Br.

Biscutella laevigata L. subsp. laevigata var. laevigata

Bunias erucago L.

Capsella bursa-pastoris (L.) Medik. subsp. bursa-pastoris

Capsella rubella Reut.

Cardamine bulbifera (L.) Crantz

Cardamine impatiens L. subsp. impatiens

RR

Conringia austriaca (Jacq.) Sweet

Draba aizoides L. subsp. aizoides

Draba verna L. subsp. verna

E - RR Erysimum majellense Polatschek - after Iocchi et al. (2010) this is the second record for Lazio, thus representing a confirmation of its presence in the region.

$\mathrm{E}$

Erysimum pseudorhaeticum Polatschek

$\mathrm{R}$

Hesperis laciniata All. subsp. laciniata

Hesperis matronalis L. subsp. matronalis

Hornungia petraea (L.) Rchb. subsp. petraea

Isatis tinctoria L. subsp. tinctoria

Microthlaspi perfoliatum (L.) F.K.Mey.

Mummenhoffia alliacea (L.) Esmailbegi \& Al-Shehbaz

Pseudoturritis turrita (L.) Al-Shehbaz

Rapistrum rugosum (L.) All.

Sinapis arvensis L. subsp. arvensis

MR

Turritis glabra L.

Loranthaceae

Loranthus europaeus Jacq.

Santalaceae

Thesium humifusum DC.

$\mathrm{R}$

Thesium linophyllon $\mathrm{L}$.

Viscum album $\mathrm{L}$.

Plumbaginaceae

$\mathrm{E}$

Armeria canescens (Host) Ebel

Polygonaceae

$\mathrm{R}$

Bistorta officinalis Delarbre

Fallopia convolvulus (L.) A. Löve

Polygonum arenastrum Boreau subsp. arenastrum

Polygonum aviculare L. subsp. aviculare

Rumex acetosa L. subsp. acetosa

Rumex acetosella L. subsp. pyrenaicus (Pourr. ex Lapeyr.) Akeroyd

$\mathrm{R}$

Rumex alpinus $\mathrm{L}$.

$\mathrm{R}$

Rumex arifolius All.

Rumex crispus $\mathrm{L}$.

Rumex scutatus L. subsp. scutatus

Caryophyllaceae

Agrostemma githago L. subsp. githago

Arenaria leptoclados (Rchb.) Guss. subsp. leptoclados 


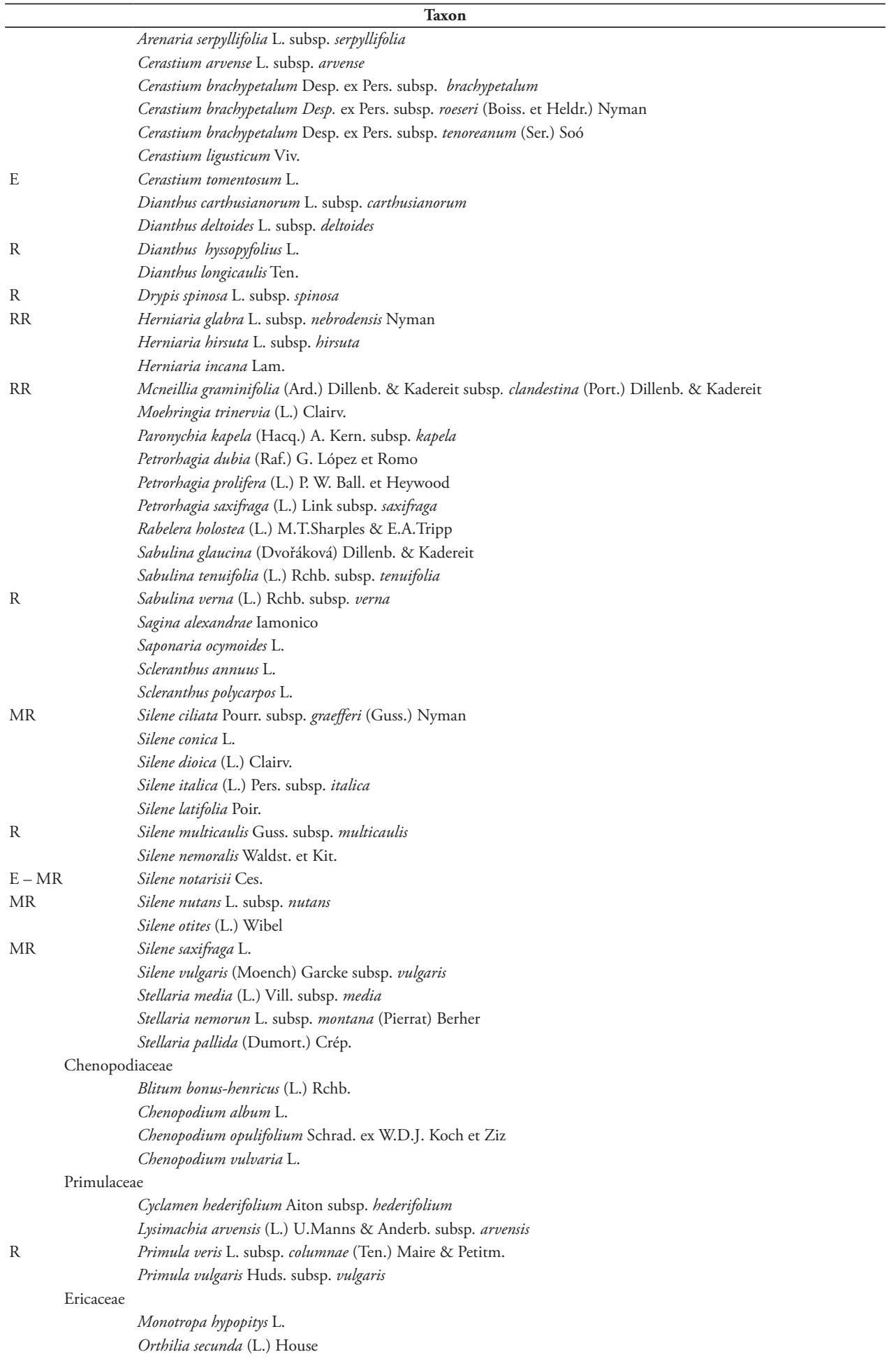




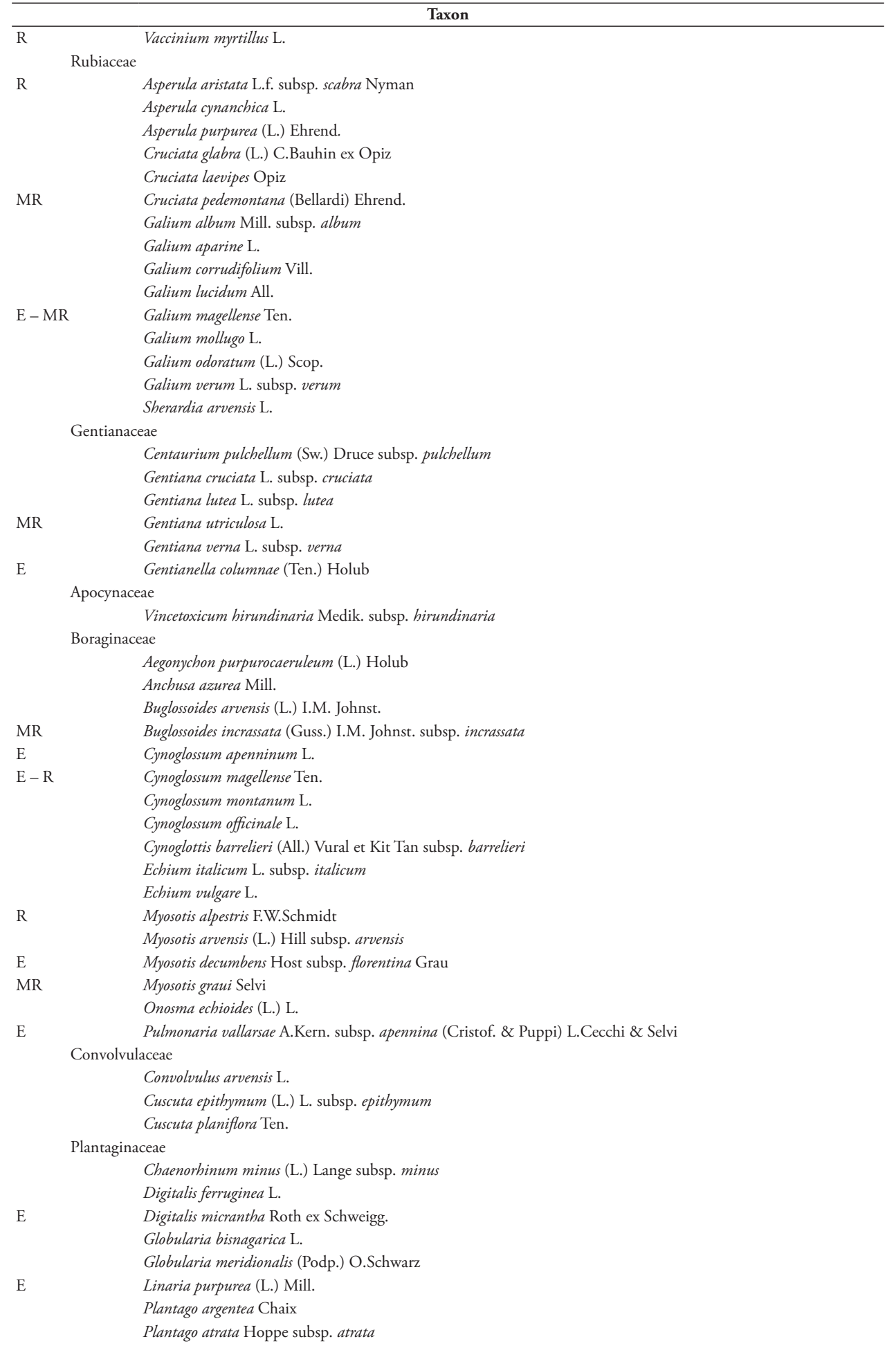




\section{Taxon}

Plantago lanceolata $\mathrm{L}$.

Plantago lanceolata L. var. sphaerostachya Mert. et W.D.J. Koch

Plantago major L. subsp. major

Plantago media L. subsp. media

Plantago sempervirens Crantz

Plantago subulata L.

Veronica anagallis-aquatica L. subsp. anagallis-aquatica

Veronica arvensis $\mathrm{L}$.

MR

Veronica barrelieri H.Schott ex Roem. \& Schult. subsp. barrelieri

Veronica beccabunga L. subsp. beccabunga

Veronica chamaedrys L. subsp. chamaedrys

Veronica cymbalaria Bodard subsp. cymbalaria

Veronica hederifolia L. subsp. hederifolia

$\mathrm{R}$

Veronica orsiniana Ten. subsp. orsiniana

NAT Veronica persica Poir.

Veronica polita Fr.

MR Veronica prostrata L.

Veronica serpyllifolia $\mathrm{L}$.

Scrophulariaceae

Scrophularia auriculata L. subsp. auriculata

Scrophularia canina L.

$\mathrm{R}$

Scrophularia juratensis Schleich.

Scrophularia nodosa L.

Scrophularia scopolii Hoppe ex Pers.

Scrophularia vernalis $\mathrm{L}$.

Verbascum longifolium Ten.

Verbascum mallophorum Boiss. et Heldr.

Verbascum pulverulentum Vill.

Lamiaceae

Ajuga chamaepitys (L.) Schreb. subsp. chamaepitys

Ajuga reptans L.

E-MR Betonica alopecuros L. subsp. divulsa (Ten.) Bartolucci \& Peruzzi

Clinopodium menthifolium (Host) Merino subsp. menthifolium

Clinopodium vulgare L. subsp. vulgare

Galeopsis angustifolia Hoffm. subsp. angustifolia

Lamium bifidum Cirillo subsp. bifidum

Lamium garganicum L. subsp. laevigatum Arcang.

Lamium maculatum $\mathrm{L}$.

Lamium purpureum $\mathrm{L}$.

Marrubium incanum Desr.

Melittis melissophyllum L. subsp. melissophyllum

Mentha longifolia (L.) L.

MR

Mentha microphylla C. Koch

Origanum vulgare L. subsp. vulgare

Prunella laciniata (L.) L.

Prunella vulgaris $\mathrm{L}$. subsp. vulgaris

Salvia glutinosa $\mathrm{L}$.

Salvia pratensis $\mathrm{L}$.

Salvia verbenaca $\mathrm{L}$.

Salvia virgata Jacq.

Stachys heraclea All.

Stachys recta L. subsp. recta

$\mathrm{R}$

Stachys recta L. subsp. subcrenata (Vis.) Briq.

Stachys tymphaea Hausskn.

Teucrium chamaedrys L. subsp. chamaedrys

Teucrium montanum $\mathrm{L}$.

Thymus longicaulis C.Presl subsp. longicaulis 


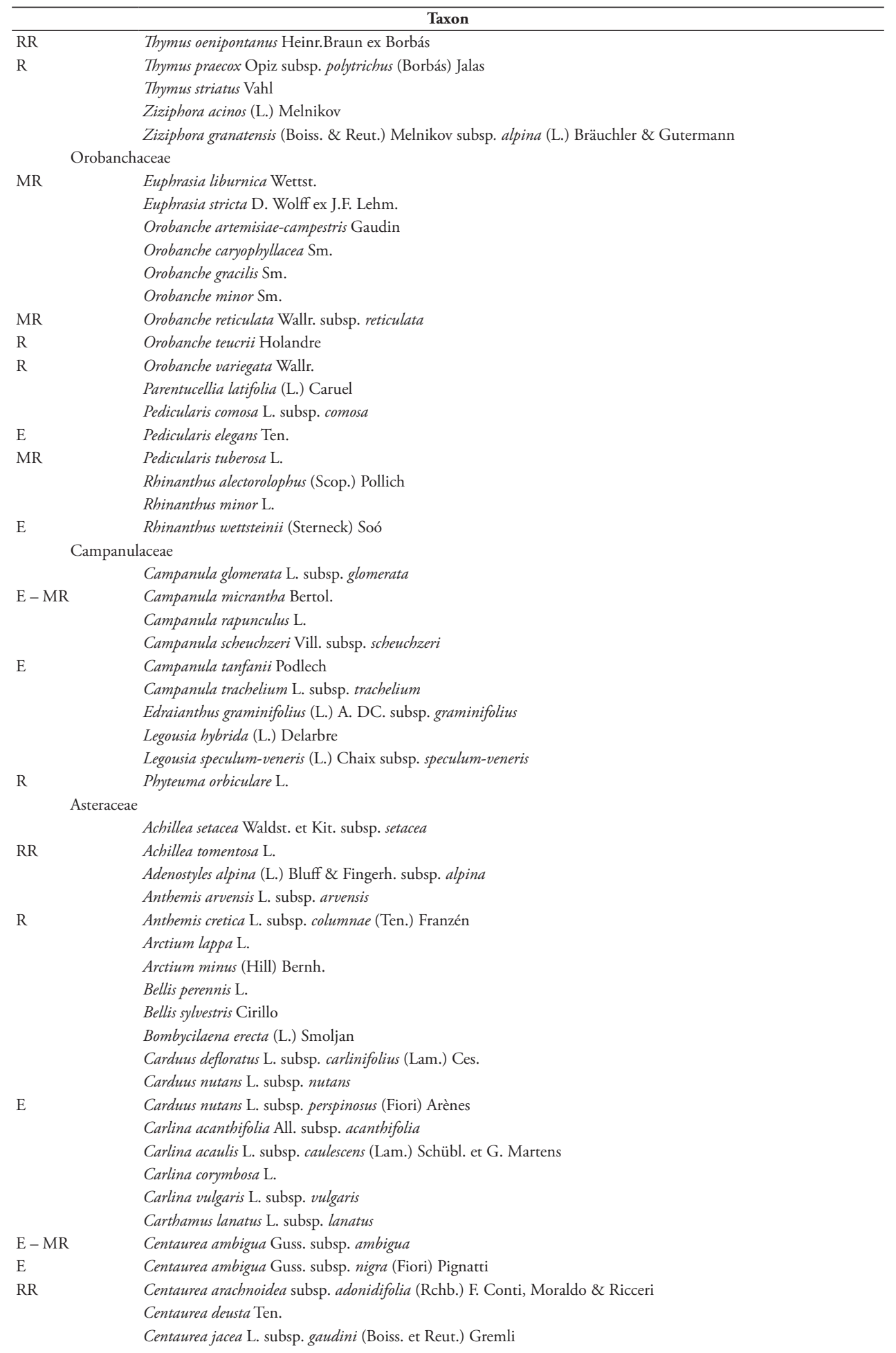




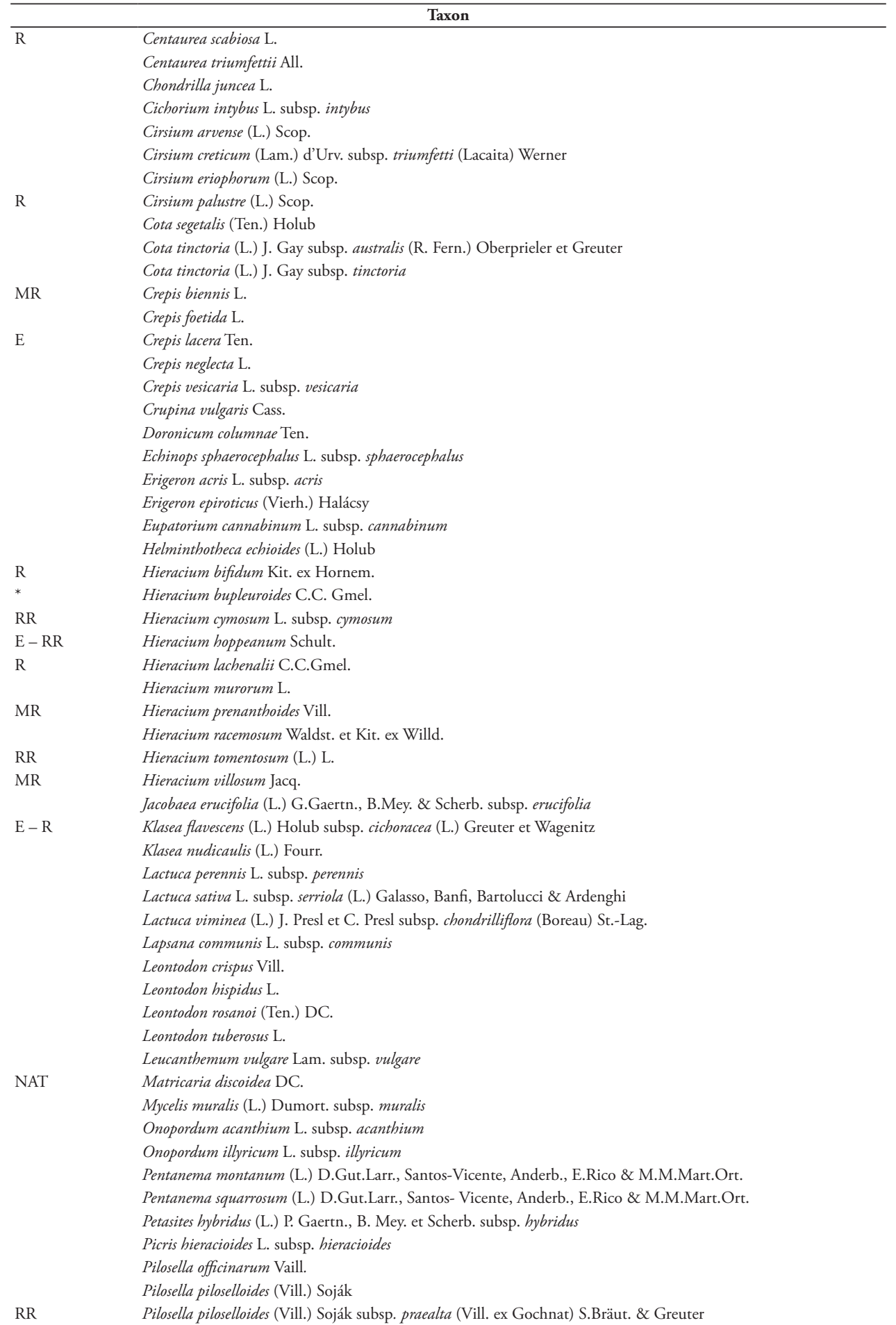




\section{Taxon}

Prenanthes purpurea $\mathrm{L}$.

Pseudopodospermum hispanicum (L.) Zaika, Sukhor. \& N.Kilian

Ptilostemon strictus (Ten.) Greuter

Pulicaria dysenterica (L.) Bernh.

Scorzonera cana (C.A.Mey.) Griseb.

RR

$\mathrm{RR}$

MR

$\mathrm{R}$

$\mathrm{R}$

$\mathrm{R}$

$\mathrm{R}$

$\mathrm{R}$

Scorzonera laciniata $\mathrm{L}$.

Scorzonera purpurea L. subsp. purpurea

Scorzoneroides cichoriacea (Ten.) Greuter

Senecio apenninus Tausch

Senecio scopolii Hoppe et Hornsch. ex Bluff et Fingerh.

Serratula tinctoria L. subsp. tinctoria var. tinctoria

Solidago virgaurea L. subsp. virgaurea

Sonchus asper (L.) Hill subsp. asper

Sonchus asper (L.) Hill subsp. glaucescens (Jord.) Ball

Tanacetum corymbosum (L.) Sch. Bip. var. corymbosum

Tanacetum corymbosum (L.) Sch. Bip. var. tenuifolium (Willd.) Briq. et Cavill.

Tanacetum parthenium (L.) Sch. Bip.

Taraxacum fulvum gr.

Taraxacum minimum (V.Brig.) N.Terracc.

Taraxacum officinale Weber

Tragopogon crocifolius $\mathrm{L}$.

Tragopogon dubius Scop.

Tragopogon porrifolius $\mathrm{L}$.

Tragopogon pratensis $\mathrm{L}$.

Tragopogon samaritani Heldr. et Sartori ex Boiss.

Tussilago farfara $\mathrm{L}$.

Xeranthemum cylindraceum Sm.

Xeranthemum inapertum (L.) Mill.

Viburnaceae

Adoxa moschatellina L. subsp. moschatellina

Sambucus ebulus L.

Sambucus nigra $\mathrm{L}$.

Dipsacaceae

Dipsacus fullonum $\mathrm{L}$.

Knautia purpurea (Vill.) Borbás

Scabiosa columbaria $\mathrm{L}$.

Caprifoliaceae

Lonicera alpigena L. subsp. alpigena

Lonicera etrusca Santi

Valerianaceae

Centranthus ruber (L.) DC. subsp. ruber

Valeriana officinalis $\mathrm{L}$.

Valeriana tuberosa $\mathrm{L}$.

Valerianella carinata Loisel.

Valerianella eriocarpa Desv.

Valerianella locusta (L.) Laterr.

Araliaceae

Hedera helix L. subsp. helix

Apiaceae

Aegopodium podagraria L.

Angelica sylvestris L. subsp. sylvestris

Anthriscus sylvestris (L.) Hoffm. subsp. sylvestris

Bunium bulbocastanum $\mathrm{L}$.

Bupleurum baldense Turra

Bupleurum falcatum L. subsp. cernuum (Ten.) Arcang.

Chaerophyllum aureum $\mathrm{L}$. 


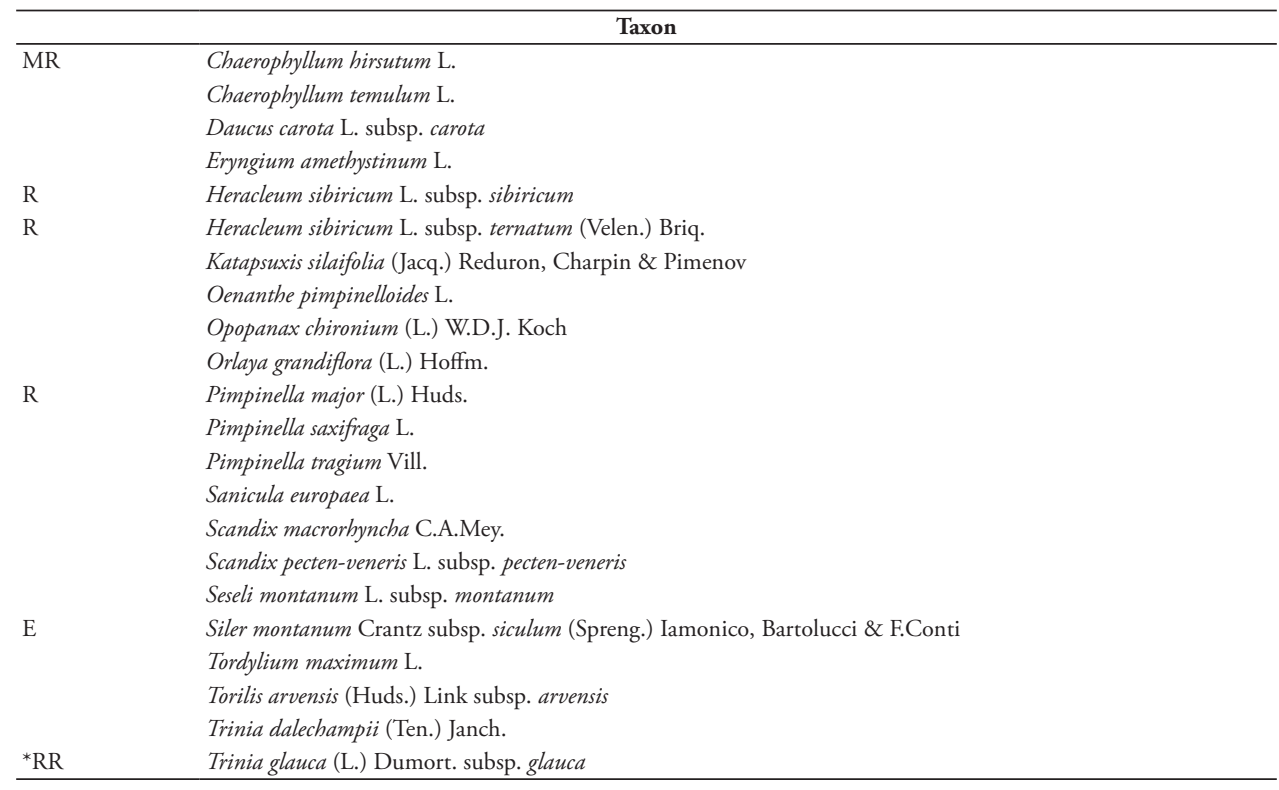

\section{Supplementary material I}

Phytosociological releves surveyed in the study area and their syntaxonomical classification

Authors: Edda Lattanzi, Eva Del Vico, Roberto Tranquilli, Emmanuele Farris, Michela Marignani, Leonardo Rosati

Data type: Table

Explanation note: Table with the phytosociological releves surveyed in the study area and their syntaxonomical classification.

Copyright notice: This dataset is made available under the Open Database License (http://opendatacommons.org/licenses/odbl/1.0/). The Open Database License $(\mathrm{ODbL})$ is a license agreement intended to allow users to freely share, modify, and use this Dataset while maintaining this same freedom for others, provided that the original source and author(s) are credited.

Link: https://doi.org/10.3897/phytokeys.178.62947.suppl1 